\title{
RNAi AND mIRNA PATHWAYS IN PLANTS I - MOLECULAR MECHANISMS
}

Keywords: dsRNA, miRNA, siRNA, Dicer, Argonaute, RdRP, RNAi, PTGS, DNA methylation

\section{PETR SVOBODA}

Institute of Molecular Genetics, Academy of Sciences of the Czech Republic, Videnska 1083, 14220 Prague 4, Czech Republic

Correspondence to: Petr Svoboda, Institute of Molecular Genetics ASCR, Videnska 1083, 14220 Prague 4, Czech Republic, tel. \#+420 241063147, e-mail: svobodap@img.cas.cz.

\begin{abstract}
RNA silencing denotes sequence-specific repression mediated by small RNAs. It includes post-transcriptional silencing mechanisms such as RNA interference (RNAi) and microRNA (miRNA) pathway and transcriptional silencing. RNA silencing regulates endogenous protein-coding gene expression, serves as a form of innate immunity targeting viruses, and protects genome integrity by repression of retrotransposons. This review provides overview of RNA silencing in flowering plants, from which comes the bulk of published data. Plants have arguably the most complex RNA silencing system among eukaryots because of existence of many paralogs of key protein factors, which form an intricate network of primary and secondary small RNAs, which mediate transcriptional and post-transcriptional effects. The first half of the review will provide a detailed catalogue of components of RNA silencing in plants while the second half will discuss the specific silencing mechanisms themselves and their biological roles, with a particular focus on the miRNA pathway, PTGS/VIG (plant's equivalent of RNAi), and transcriptional gene silencing (TGS), which is a unique RNA silencing adaptation existing in plants.
\end{abstract}

\section{Introduction}

Plants are extremely large and diverse group of multicellular organisms. Among their defining features are cell walls are made of cellulose, the ability to perform photosynthesis in chloroplasts, double membrane organelles containing chlorophyll $\mathrm{a} / \mathrm{b}$, and use of starch to store photosynthetic products. There are $\sim 500000$ described species (Margulis and Schwartz, 1998), which are classified in 10-12 phyla by different taxonomical concepts. In this review, I will focus on so-called angiosperms (phylum Magnoliophyta or Anthophyta), which is the most populous plant phylogenetic group (Palmer et al., 2004) and from which are most data concerning RNA silencing in plants. 
RNA silencing is extremely convoluted in plants. It is the most complex RNA silencing among the reviewed taxons thanks to existence of many Dicer, Argonaute, and RNA-dependent RNA polymerase (RdRP) paralogs, which fucntion in an intricate network of primary and secondary small RNAs, which mediate transcriptional and post-transcriptional effects. The nomenclature of small RNAs in plants is complex and arbitrary; small RNAs include miRNAs and various types of siRNAs produced from ds RNA, which are distinguished by their origin (viral siRNA), biogenesis (phased siRNAs) or their effect (heterochromatinizing siRNAs). RNA silencing in plants can be divided in three to four main systems: miRNA, RNAi/ post-transcriptional gene silencing (PTGS), antiviral defense/ virus-induced gene silencing (VIGS), and transcriptional gene silencing (TGS) (Bologna and Voinnet, 2014; Bonnet et al., 2006; Borges and Martienssen, 2015; Carbonell and Carrington, 2015; Chen, 2009; Galun, 2005; Mallory et al., 2008; Van Ex et al., 2011; Vazquez, 2006; Zhang et al., 2015).

Here, I will focus on data from Arabidopsis thaliana and first review the molecular features of key individual components of RNA silencing related to the miRNA pathway and dsRNA response - Dicers, Argonautes, and RdRPs. In the second half of this review, I will discuss the reviewed mechanisms themselves and their biological roles, with a particular focus on the miRNA pathway, PTGS/VIG - plant's equivalent of RNAi, and transcriptional gene silencing (TGS), which is a unique adaptation found in plants. Unless specifically stated, presented information comes from the Arabidopsis thaliana model.

\section{Dicer proteins - DCL1-4 and additional Dicer family members}

Plants have specialized and compartmentalized Dicer (Dicer-like - DCL) proteins that act partially redundantly and hierarchically in small RNA production in different pathways miRNA, antiviral defense, endo-RNAi pathways, or chromatin remodelling (Liu et al., 2009b; Moissiard and Voinnet, 2006; Xie et al., 2005). The "basal" plant state found in Arabidopsis (or, for example, cotton (Silva et al., 2011)) is four Dicers, which presumably evolved through duplications of an ancestral Dicer (Margis et al., 2006). Some plants (such as monocots) have higher counts of Dicer homologs - there are five in poplar and eight in rice; the additional Dicers evolved through duplications of one of the four "basic" plant Dicers (Kapoor et al., 2008; Margis et al., 2006; Mukherjee et al., 2013).

Plant Dicer proteins are large multidomain proteins, which have essentially the same domain organization as animal Dicers (Fig. 1), i.e. they are composed of domains ordered from the $\mathrm{N}$ - to the $\mathrm{C}$-terminus as follows: N-terminal DExD and helicase superfamily C-terminal domains, a domain of unknown function DUF283 (not annotated in DCL-3 of Arabidopsis thaliana but annotated in poplar and rice DCL3), a PAZ domain, RNase IIIa and RNase IIIb domains, and the C-terminal dsRBD. The four plant Dicers differ in size and the number of dsRBD domains - DCL1, DCL3, and DCL4 have an additional dsRBD (Fig. 1). Although none of the plant Dicers has been either crystallized or analyzed by cryo-EM, the conserved domain organization and available biochemical data suggest that plant Dicers operate under the same principles as animal Dicers despite their functional diversification. In general, DCL1 is mainly functioning in the miRNA pathway while 


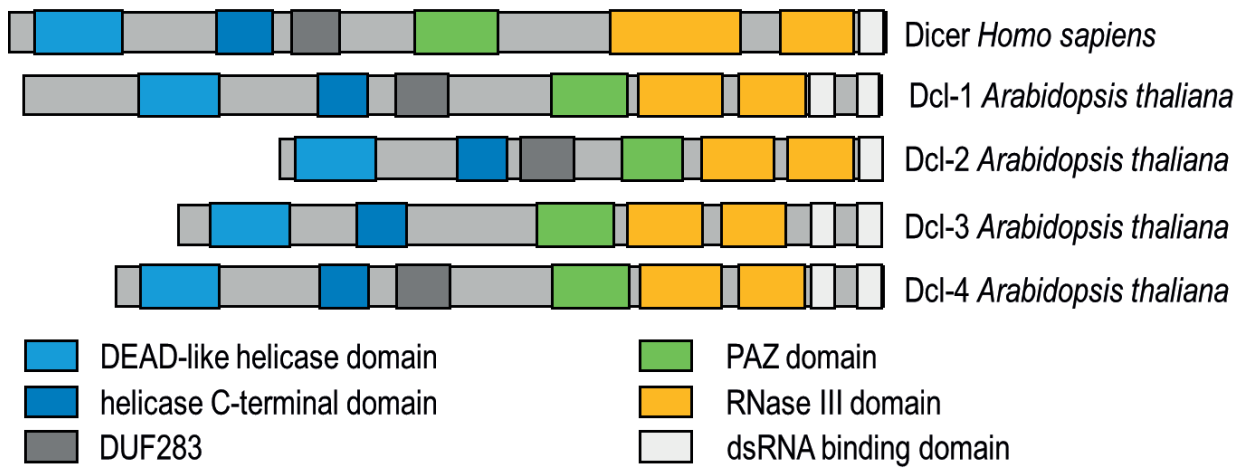

Figure 1 Comparison Dicer protein domain composition among Dicer proteins in A. thaliana, and C. elegans

Domain composition was adopted from (Jaskiewicz and Filipowicz, 2008).

DCL2, 3, 4 produce siRNAs for silencing mobile elements or in antiviral defense where DCL3 represents the nuclear arm of the defense, which is distinguished by production of longer siRNAs (24 nt). Detailed review of individual DCL proteins is provided further below:

\section{DCL1 - miRNA biogenesis \& PTGS}

DCL1 is the oldest known and possibly best characterized member of the DCL gene family in Arabidopsis. DCL1 was repeatedly recovered from mutation screens in plants since early 90's and it has been given several names (EMBRYO DEFECTIVE76 (EMB76), SHORT INTEGUMENTS1 (SIN1), SUSPENSOR1 (SUS1) and CARPEL FACTORY (CAF)) prior recognizing that it is a factor closely related to Dicer proteins acting in RNA silencing in animals (Schauer et al., 2002). DCL1 was first shown to be required for biogenesis of miRNAs but not siRNAs (Park et al., 2002; Reinhart et al., 2002). The size of the cleavage product is $21 \mathrm{nt}$, a nucleotide shorter than average length of animal miRNAs (Fig. 2).

DCL1 contains two putative nuclear localization signals and it localizes to the nucleus where it produces small RNAs (Papp et al., 2003). Furthermore, it was shown that DCL1 is also able to produce $21 \mathrm{nt}$ from a transgenic inverted repeat (Papp et al., 2003).

DCL1 operates with a dsRBD binding partners DRB1 and DRB2 (Curtin et al., 2008; Reis et al., 2016; Reis et al., 2015b). Interestingly, DCL1 represses antiviral RNA silencing through negatively regulating the expression of DCL4 and DCL3 (Qu et al., 2008). DCL1 is an essential gene in Nicotiana attenuata (Bozorov et al., 2012) and its miRNA function is conserved in tomato (Kravchik et al., 2014b).

\section{DCL2}

DCL2 functions in the antiviral response (Curtin et al., 2008; Donaire et al., 2008; Fusaro et al., 2006; Ogwok et al., 2016; Urayama et al., 2010; Zhang et al., 2012) where it produces 
miRNA size distribution in A. thaliana

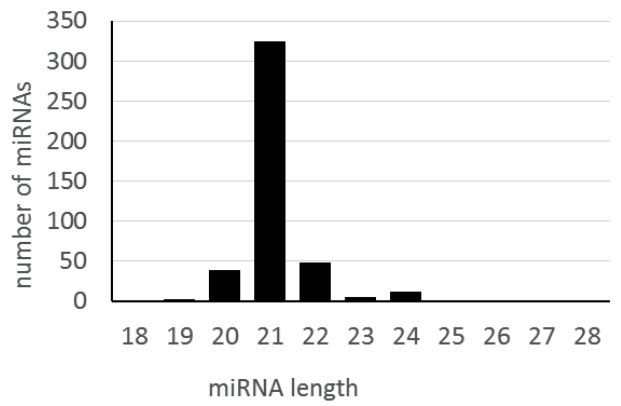

miRNA size distribution in Mus musculus

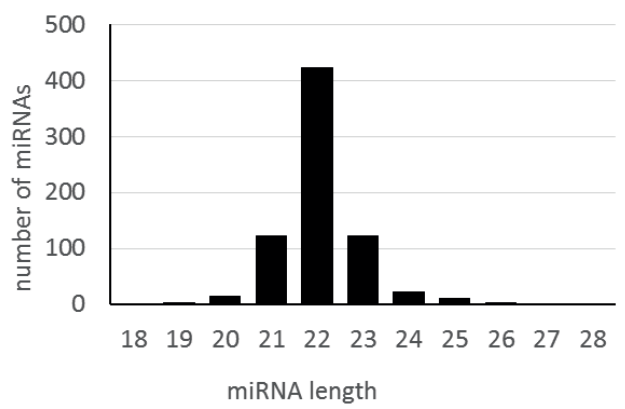

Figure 2 Arabidopsis miRNA size distribution Distribution of Arabidopsis mature miRNA lengths according to miRNA annotations in miRBase (Kozomara and Griffiths-Jones, 2014).

viral siRNAs without requiring assistance from any dsRBP. (Curtin et al., 2008). DCL2 was also implicated in 21/22 nt siRNA production from longer intronic hairpins (sirtrons) (Chen et al., 2011). DCL2 acts hierarchically with DCL4 to produce 22- and 21-nt siRNAs in antiviral resistance and amplification of silencing mediated by RNA-dependent RNA polymerase RDR6 (Brosnan et al., 2007; Deleris et al., 2006; Di Serio et al., 2009; Garcia-Ruiz et al., 2010; Ogwok et al., 2016; Parent et al., 2015). DCL2 can substitute DCL4 and produce 22nt viral siRNAs even in the absence of DCL4, (Bouche et al., 2006; Moissiard et al., 2007; Wang et al., 2011). Under some circumstances, DCL2 can antagonize production of miRNAs and siRNAs by DCL1 (Bouche et al., 2006).

DCL2 is required for transitive cell-autonomous post-transcriptional silencing of transgenes (Mlotshwa et al., 2008) and it was implicated in the transgenerational stress memory (Boyko and Kovalchuk, 2010; Migicovsky and Kovalchuk, 2014; Migicovsky and Kovalchuk, 2015; Migicovsky et al., 2014). Two paralogs of DCL2 were found in Medicago truncatula where are DCL genes differentially expressed during symbiosis with nitrogen fixing bacteria and upon pathogen infection (Tworak et al., 2016). Two paralogs of DCL2 were also found in soybean where DCL2 showed the strongest transcriptional response to stress (Curtin et al., 2012).

\section{DCL3}

DCL3 is producing longer siRNAs (24 nt) than the other three DCL proteins in Arabidopsis and other plants, including tomato, rice, medick, or moss (Coruh et al., 2015; Kravchik et al., 2014a; Tworak et al., 2016; Wei et al., 2014). DCL3 preferentially cleaves dsRNAs with 5' phosphorylated adenosine or uridine and a $1 \mathrm{nt} 3$ ' overhang (Nagano et al., 2014) and produces 24 nt RNA duplexes with 2 nt 3' overhangs; inorganic phosphate, $\mathrm{NaCl}$ and $\mathrm{KCl}$ enhance DCL3 activity (Kravchik et al., 2014a).

DCL3 long dsRNA substrates are typically generated from RNA polymerase IVa/IV and $\mathrm{IVb} / \mathrm{V}$ (Pol IV and Pol V hereafter) transcripts by RDR2 (Daxinger et al., 2009; Zhang 
et al., 2007). DCL3 co-localizes with RDR2, AGO4, NRPD1b (the largest Pol V subunit) and siRNAs within the nucleolus (Pontes et al., 2006).

DCL3 was implicated in $24 \mathrm{nt}$ siRNA production from longer intronic hairpins (sirtrons), which were associated with AGO4 and could mediate RNA-dependent DNA methylation (RdDM) (Chen et al., 2011), and in production of viral 24 nt siRNAs (Akbergenov et al., 2006; Curtin et al., 2008; Diaz-Pendon et al., 2007; Donaire et al., 2008; Fusaro et al., 2006; Raja et al., 2014). DCL3 can produce viral siRNAs without requiring assistance from any dsRBP (Curtin et al., 2008) but, it was also shown that it can function with DRB3 and AGO4 in methylation-mediated antiviral defense (Raja et al., 2014). Interestingly, the loss of DCL3 is partially complemented by DCL4 and DCL2, which produce 21/22 nt small RNAs (Kravchik et al., 2014a) indicating partial functional redundancy of DCL2/3/4 in recognition of dsRNA and silencing.

DCL3 and RDR2 were also implicated in production of a pseudogene-derived $24 \mathrm{nt}$ siRNAs in rice (Guo et al., 2009). DCL3b paralog in rice functions in processing of $24 \mathrm{nt}$ phased small RNAs in miRNA targeted loci suggesting functional divergence of DCL3 paralogs in rice (Song et al., 2012). DCL3 was suggested to participate also in the transgenerational stress memory (Boyko and Kovalchuk, 2010; Migicovsky and Kovalchuk, 2014; Migicovsky and Kovalchuk, 2015; Migicovsky et al., 2014).

Finally, DCL3, RDR2 and Pol IV, also operate in production of 24 nt small RNAs from miRNA loci, which are loaded on AGO4 and mediate RdDM (Chellappan et al., 2010; Wu et al., 2010). DCL3 may be absent in conifers, which radiated from other seed-bearing plants approximately 260 million years ago; there were no significant amounts of $24 \mathrm{nt}$ siRNAs in growing shoot tissue while no evidence for DCL3 was found (Dolgosheina et al., 2008).

\section{DCL4}

DCL4 cleaves long dsRNAs with blunt ends or with a 1 or 2 nt 3' overhang with similar efficiency; inorganic phosphate, $\mathrm{NaCl}$ and $\mathrm{KCl}$ inhibit DCL4 activity (Nagano et al., 2014). DCL4 operates with DRB4 to produce $21 \mathrm{nt}$ trans-acting siRNAs (tasiRNAs, they are $21 \mathrm{nt}$ siRNAs produced from discrete loci (TAS genes). and siRNAs from viral RNA. (Curtin et al., 2008; Fusaro et al., 2006; Nakazawa et al., 2007; Qu et al., 2008). DCL4 alone was sufficient for antiviral silencing in leaves inoculated with Turnip mosaic virus (Garcia-Ruiz et al., 2010). While DCL4 is important for biogenesis of tasiRNA and antiviral response, it does not participate in the miRNA pathway (Xie et al., 2005).

DCL4 acts hierarchically with DCL2 to produce 21- and 22-nt siRNAs and in antiviral resistance and amplification of silencing mediated by RDR6 (Brosnan et al., 2007; Deleris et al., 2006; Di Serio et al., 2009; Garcia-Ruiz et al., 2010; Howell et al., 2007; Liu et al., 2007; Ogwok et al., 2016; Parent et al., 2015; Qu et al., 2008). The dcl4-2 mutants lack each of three families of 21-nt tasiRNAs, have elevated levels of tasiRNA target transcripts, and display heterochronic defects similar to RDR6 mutants (Xie et al., 2005). Furthermore, different double mutant phenotypes also suggested hierarchical redundancy among DCL activities leading to alternative tasiRNA biogenesis in the absence of DCL4 (Xie et al., 2005). 
DCL4 also operates (again, hierarchically with DCL2) in biogenesis of secondary siRNAs in transitive RNAi (Mlotshwa et al., 2008; Moissiard et al., 2007) and it was implicated in 21/22 nt siRNA production from longer intronic hairpins (sirtrons) (Chen et al., 2011)

Two paralogs of DCL4 exist in Medicago truncatula where DCL genes are differentially expressed during symbiosis with nitrogen fixing bacteria and upon pathogen infection (Tworak et al., 2016).

\section{dsRBPs -DRB1-5}

While DCLs act redundantly and hierarchically, there is little if any redundancy or hierarchy among DRBPs in their Dicer-associated functions. Arabidopsis genome encodes five DRBs composed of two types of dsRBDs that form a distinct clade (Clavel et al., 2016). Two additional proteins carrying dsRBDs (At1g80650 and At4g00420, renamed AtDRB7.1 and AtDRB7.2, respectively) were localized in the Arabidopsis genome. They differ from DRB1-5 in terms of dsRBD composition (Clavel et al., 2016). DRB1 and DRB2 associate with DCL1, DRB4 with DCL4, while DCL2 and DCL3 produce viral siRNAs without requiring assistance from any dsRBP. (Curtin et al., 2008).

\section{DRB1/HYL1}

DRB1 has two dsRBDs separated by a linker of $\sim 20$ amino acids (Clavel et al., 2016). DRB1 is a nuclear dsRBP exclusively functioning together with DCL1 and a small RNA methyltransferase HEN1 in miRNA biogenesis (Curtin et al., 2008; Vazquez et al., 2004). This role seems conserved across plants; its homologs were found in all tested plant genomes (Clavel et al., 2016; You et al., 2014). In association with DCL1 it directs the guide strand selection for AGO loading (Eamens et al., 2009) and determines the slicing mode of action of the miRNA-loaded AGO1 (Reis et al., 2015b). It also interacts with a hairpin in short interspersed element SB1 RNA and facilitates DCL1-mediated production of small RNAs from these repetitive elements (Pouch-Pelissier et al., 2008). DRB1 is phosphorylated by mitogen activated protein kinase MPK3 in both rice and Arabidopsis (Raghuram et al., 2015).

\section{DRB2}

DRB2 proteins possess two dsRBDs separated by a linker of 19 amino acids (Clavel et al., 2016). DRB2 is involved in miRNA biogenesis (Eamens et al., 2012a) where it, in association with DCL1, determines the translational repression of miRNA-loaded AGO1 (Reis et al., 2015b). DRB2 is involved in the processing stage of the biogenesis of non-canonical miRNA subsets while DRB3 and DRB5 are somehow required downstream to mediate RNA silencing of DRB2-associated miRNA target genes (Eamens et al., 2012b). The role of DRB2 in the miRNA pathway is distinct from that of DRB1 as shown by proteomic analysis of drb1 and drb2 mutants, which suggested that DRB2-associated translational inhibition appears to be less ubiquitous and specifically aimed toward responses against 
environmental stimuli (Reis et al., 2015c). DRB2 acts redundantly with DRB3 and DRB5 during development and appears unnecessary for other types of plant small RNAs, such as miRNA, tasiRNA, viral siRNA, or heterochromatinising siRNA production (Curtin et al., 2008). The loss of DRB2 protein in Arabidopsis results in increased levels of Pol IV dependent siRNAs, which are involved in RdDM. It was proposed that DRB2 is part of epigenetic regulation suppressing transcription of transposable elements (Clavel et al., 2015; Pelissier et al., 2011).

\section{DRB3}

DRB3 proteins possess two dsRBDs separated by a linker of 19 amino acids (Clavel et al., 2016). DRB3 participates to the RdDM defense against Geminiviruses (Raja et al., 2014). At the same time, it appears unnecessary for miRNA, tasiRNA, viral siRNA, or heterochromatinising siRNA production but acts redundantly DRB2 and DRB5 during development (Curtin et al., 2008). DRB3 is participates in RNA silencing of target genes of DRB2-associated non-canonical miRNAs (Eamens et al., 2012b).

\section{DRB4}

DRB4 protein and its relatives carry three dsRBDs. They are found in all vascular plants but were absent in the tested bryophyte and lycophyte genomes (Clavel et al., 2016). DRB4 operates with DCL4 to produce $21 \mathrm{nt}$ tasiRNAs and 21nt siRNAs from viral RNA (Curtin et al., 2008; Jakubiec et al., 2012; Qu et al., 2008; Shivaprasad et al., 2008). DRB4 expression is regulated by E3 ubiquitin ligase APC/C (Anaphase Promoting Complex or Cyclosome). APC10 interacts with DRB4 through the second dsRBD of DRB4, which is also required for its homodimerization and binding to DCL4 (Marrocco et al., 2012). In contrast to the loss of DRB2 protein in Arabidopsis, the loss of DRB4 results in reduced levels of Pol IV dependent siRNAs, which are involved in RdDM (Pelissier et al., 2011).

\section{DRB5}

DRB5 proteins possess two dsRBDs separated by a linker of 19 amino acids (Clavel et al., 2016). DRB5 appears unnecessary for miRNA, tasiRNA, viral siRNA, or heterochromatinising siRNA production but acts redundantly with DRB2 and DRB3 during development (Curtin et al., 2008). DRB5 is somehow required downstream to mediate RNA silencing of target genes of DRB2-associated non-canonical miRNAs (Eamens et al., 2012b). DRB3 was shown to associate with DCL2 and AGO4 in the RdDM arm of antiviral defense against Geminiviruses (Raja et al., 2014).

\section{DRB6}

DRB6 proteins carry two dsRBDs and are present in all vascular plants except for bryophytes, lycophytes and Brassicaceae species (Clavel et al., 2016). Their biological significance is unknown. 


\section{DRB7}

The DRB7 family has a single dsRBD; there are two members AtDRB7.1 and AtDRB7.2. Their role is largely unknown but it was found that they interact with DRB4 but not with DCL4 in Arabidopsis (Clavel et al., 2016).

\section{Argonaute proteins}

Plants show quite some variability in the AGO homolog pool. For example, Arabidopsis thaliana has 10 AGO genes (Table 1), Oryza sativa has 19, Glycine max (soybean) has 22 (Zhang et al., 2015), Solanum lycopersicum 15 (Bai et al., 2012). A dicot plant Sativa miltiorhiza (red sage) has $10 \mathrm{AGO}$ genes of which AGO1, 2, 3, 7, and 10 were proposed to function similarly to their $A$. thaliana counterparts (Shao and $\mathrm{Lu}, 2013$ ). A systematic survey of 32 plant genomes showed that plants have 6-24 AGO homologs per genome, most often more than 10 (Mirzaei et al., 2014). AGO proteins are phylogenetically divided into three clades, which also reflect different classes of bound small RNAs - clades I and II bind 21-22 nt small RNAs while the clade III accommodates longer ( 24 nt small RNAs) (Zhang et al., 2015). The phylogenetic analysis shows that the varying number of homologs in each species stems from multiple duplication events, which occurred during evolution of different taxons such that some species contain multiple paralogs of an ancestral AGO, which can be present in a single copy in another plant species.

AGO proteins loaded with different types of small RNAs play diverse roles in terms of molecular mode of action mechanisms and biological function. Small RNAs are sorted onto specific AGO proteins based on different factors, which might include subcellular localization or the DCL protein that is producing a particular small RNA. One of the key factors contributing to sorting of small RNAs onto AGO proteins is also the 5' terminal nucleotide. For example, AGO1 favors miRNAs with a 5' terminal uridine, AGO2 and AGO4 prefer small RNAs with a 5' terminal adenosine, AGO5 with a 5' terminal cytosine (Mi et al., 2008; Takeda et al., 2008).

\section{AG01}

Arabidopsis AGO1 gave the name to the entire Argonaute protein family because agol mutants were having a phenotype reminiscent of the tentacles of an Argonauta squid (Bohmert et al., 1998). Arabidopsis has a single AGO1 gene, rice has four paralogs (Wu et al., 2009). AGO1 preferentially binds miRNAs and small RNAs with a 5' uridine (Bohmert et al., 1998; Jeong et al., 2013; Mi et al., 2008; Rogers and Chen, 2013; Vaucheret et al., 2004; Wu et al., 2009). Analysis of miRNAs loaded onto AGO1 paralogs in rice suggested that a subset of miRNAs is specifically incorporated into or excluded from one of these paralogs suggesting they have both redundant and specialized roles in rice (Wu et al., 2009). AGO1 also associates with tasiRNAs. In contrast to miRNAs, tasiRNAs involve RdRP-mediated conversion of cleaved TAS RNA into dsRNA followed by production of phased tasiRNAs (i.e. secondary small RNAs) by DCL-4, which are loaded onto AGO1 (Vaucheret, 2005). 
Table 1 Overview of Argonaute proteins in Arabidopsis thaliana.

\begin{tabular}{|c|c|c|c|c|c|c|c|}
\hline \multirow{2}{*}{$\begin{array}{l}\text { common } \\
\text { name }\end{array}$} & \multirow{2}{*}{ subfamily } & \multirow{2}{*}{ slicer } & \multicolumn{5}{|c|}{ associated small RNA } \\
\hline & & & type & length & 5'nt & 5' end & 3' end \\
\hline AGO1 & plant AGO clade I & + & miRNA & 21 & $\mathrm{U}$ & mono-P & 2'-O-met \\
\hline AGO2 & plant AGO clade II & + & $\begin{array}{l}\text { miRNAs, tasiRNAs, } \\
\text { rasiRNAs }\end{array}$ & 21 & A & mono-P & 2'-O-met \\
\hline AGO3 & plant AGO clade II & + & siRNAs & 24 & A & mono-P & 2'-O-met \\
\hline AGO4 & plant AGO clade III & + & $\begin{array}{l}\text { intergentic siRNAs, } \\
\text { rasiRNAs }\end{array}$ & $23-24$ & A & mono-P & 2'-O-met \\
\hline AGO5 & plant AGO clade I & + & intergenic siRNA & $21,22,24$ & $\mathrm{C}$ & mono-P & 2'-O-met \\
\hline AGO6 & plant AGO clade III & + & siRNAs & 24 & A & mono-P & 2'-O-met \\
\hline AGO7 & plant AGO clade II & + & $\begin{array}{c}\text { miRNA (miR390), } \\
\text { ta-siRNA }\end{array}$ & 21 & A & mono-P & 2'-O-met \\
\hline AGO8 & plant AGO clade III & $(+)$ & - & - & - & - & - \\
\hline AGO9 & plant AGO clade III & $(+)$ & rasiRNAs & 24 & $\mathrm{~A}$ & mono-P & 2'-O-met \\
\hline AGO10 & plant AGO clade I & + & $\operatorname{miRNA}(\operatorname{mir} 165 / 166)$ & 21 & $\mathrm{U}$ & mono-P & 2'-O-met \\
\hline
\end{tabular}

\section{AGO2}

AGO2 is a slicing AGO (Carbonell et al., 2012) but can also directly repress translation (Fatyol et al., 2016). It favors small RNAs with a 5' terminal adenosine (Mi et al., 2008; Takeda et al., 2008), which include miR393*, regulating antibacterial innate immunity (Zhang et al., 2011). AGO2 plays a role in the natural cis-antisense (natsiRNA) pathway (Oliver et al., 2014). AGO2 also mediates antiviral defense (Jaubert et al., 2011; Odokonyero et al., 2015) and was implicated (together with a plant-specific GW protein NERD) in nuclear silencing of a set of non-conserved genomic loci (Pontier et al., 2012). In addition, AGO2 was also associated with diRNAs, small RNAs emerging during double-stranded break repair (Oliver et al., 2014; Wei et al., 2012).

\section{AGO3}

Drosophila AGO3 is a close paralog apparently emerging through a genome duplication of the AGO2 locus (Vaucheret, 2008). Interestingly, rice and maize lack the AGO3 ortholog but have a pair of AGO2 genes instead (Kapoor et al., 2008; Zhai et al., 2014).

\section{AGO4}

AGO4 preferentially recruits 24 nt small RNAs with a 5' terminal adenosine (Havecker et al., 2010; Mi et al., 2008) and mediates RNA-directed DNA methylation (Havecker et al., 2010; He et al., 2009; Wu et al., 2010; Xie and Yu, 2015; Zilberman et al., 2004). AGO4-loaded small RNAs are often DCL-3 produced repeat and heterochromatin-associated siRNAs from introns and intergenic regions (Chen et al., 2011; He et al., 2009; Xie 
and Yu, 2015; Zheng et al., 2009; Zilberman et al., 2004) but can also be DCL-4 produced tasiRNAs (Wu et al., 2012). In rice, it was even found that RNA-directed DNA methylation can be guided by a specific miRNA class produced by DCL3 (Wu et al., 2010). AGO4 is also coupled to antibacterial (Agorio and Vera, 2007) and antiviral innate immunity (Jones et al., 2006; Ma et al., 2015; Minoia et al., 2014; Raja et al., 2014).

\section{AGO5}

AGO5 is highly enriched in the germline (Oliver et al., 2014). It binds preferentially $21 \mathrm{nt}$ small siRNAs (phased small RNAs, phasiRNAs) with a 5' terminal cytosine (Komiya et al., 2014; Mi et al., 2008; Takeda et al., 2008). It also binds miRNAs and mediates miRNA-directed target cleavage (Oliver et al., 2014). Arabidopsis AGO5 has been implicated in female gametogenesis (Tucker et al., 2012) and in antiviral defense (Brosseau and Moffett, 2015). MEL1, AGO5 homolog in rice, has specific functions in the development of pre-meiotic germ cells and the progression of meiosis (Komiya et al., 2014).

\section{AGO6}

AGO6 preferentially recruits 24 nt RNAs with a 5' terminal adenosine (Havecker et al., 2010). AGO6 mediates RNA-directed DNA methylation (Eun et al., 2011; Havecker et al., 2010; McCue et al., 2015; Zheng et al., 2007). AGO6 participates in RNA-directed DNA methylation of transcriptionally active transposable elements through incorporation of fragments of PTGS-targeted transcripts of transposable elements onto AGO6 (McCue et al., 2015). AGO6 can also accommodate DCL4-produced produced tasiRNAs (Wu et al., 2012).

\section{AGO7}

AGO7 was originally named ZIPPY and was primarily associated with the regulation of developmental timing and did not have a significant role in transgene silencing (Hunter et al., 2003). It was subsequently found that AGO7 is preferentially loaded with miR390 and triggers production of tasiRNAs from the TAS3 locus (Garcia et al., 2006; Montgomery et al., 2008). TAS3-derived tasiRNA target AUXIN RESPONSE FACTORS and regulate leaf patterning and lateral organ separation (Montgomery et al., 2008; Zhou et al., 2013). This role of AGO7 appears conserved across plants as it has been also reported from rice (Nagasaki et al., 2007; Shi et al., 2007) and maize (Douglas et al., 2010).

\section{AGO8 - seems to be a pseudogene in A. thaliana (Zhang et al., 2015)}

\section{AGO9}

AGO9 is involved in RNA-directed DNA methylation and is highly enriched in the germline (Oliver et al., 2014) where it controls female gamete formation by repressing 
the specification of germ cell fate through epigenetic reprogramming in companion somatic cells (Olmedo-Monfil et al., 2010). Zea mays AGO2 homolog (originally designated ZmAGO104) is also specifically expressed in the somatic cells surrounding future gametes but it had an opposing function - it suppresses the somatic cell fate in germ cells (Singh et al., 2011).

\section{AG010}

AGO10 is the closest homolog of AGO1 and its main role appears to be sequestration of miR156/166 miRNA family from AGO1 (Zhou et al., 2015; Zhu et al., 2011). The targets of miR166/165 are class III HOMEODOMAIN-LEUCINE ZIPPER transcription factors, which determine the shoot apical meristem fate. According to the model, AGO10 uses its higher binding affinity for miR166/165 and functions as a decoy, preventing loading of miR166/165 onto AGO1, hence preventing their suppression and allowing for proper regulation of the shoot apical meristem (Brandt et al., 2013; Ji et al., 2011; Liu et al., 2009a; Roodbarkelari et al., 2015; Tucker et al., 2013; Zhou et al., 2015; Zhu et al., 2011).

\section{Additional relevant homologs}

Monocot genomes encode for AGO18 homologs, which are not found in dicots, such as A. thaliana (Zhang et al., 2015). In rice, AGO18 is important for antiviral defense (Wu et al., 2015).

\section{RdRPs}

The first RdRP homolog found in plants was RdRP from tomato (Schiebel et al., 1993; Schiebel et al., 1998). Arabidopsis genome carries six RdRP genes: RDR1-RDR6 (Yu et al., 2003). There are five RdRPs in Salvia miltiorrhiza (Shao and Lu, 2014) and six in potato Solanum lycopersicum (Lin et al., 2016). Plant RdRPs are homologs of RdRPs acting in RNA silencing in other kingdoms, such as QDE-3 in Neurospora (Salgado et al., 2006; Wassenegger and Krczal, 2006), suggesting that they evolved from a single ancestral RdRP acting in RNA silencing. RdRPs produce dsRNA that can enter the RNA silencing pathway. Hence, they either initiate RNA silencing or function as an amplifier of an already present dsRNA response.

\section{$R D R 1$}

RDR1 (also known as SDE1/SGS2) in Arabidopsis and its homologs in other plant species contribute to RNA silencing-based resistance to virus infection (Blevins et al., 2011; Cao et al., 2014; Diaz-Pendon et al., 2007; Garcia-Ruiz et al., 2010; Leibman et al., 2011; Muangsan et al., 2004; Vaistij et al., 2002; Yang et al., 2004; Yu et al., 2003). It was also implicated in biogenesis of tasiRNAs during juvenile development (Peragine et al., 2004). 


\section{RDR2}

RDR2 has been linked with transcriptional silencing in the nucleus and RdDM of specific loci (Chan et al., 2004; Xie et al., 2004). It participates in biogenesis of endogenous siRNAs (natsiRNAs) (Borges and Martienssen, 2015; Brosnan et al., 2007). RDR2 is not required for production of viral siRNAs from the Cauliflower mosaic pararetrovirus (Blevins et al., 2011), Cabbage leaf curl geminivirus (Aregger et al., 2012). RDR3 converts PolIV transcripts into dsRNA, which is processed by DCL3 into 24 nt siRNAs loaded onto AGO4 (Pontes et al., 2006; Zhang et al., 2007). RDR2 and DCL3 were implicated in production of pseudogene-derived $24 \mathrm{nt}$ siRNAs in rice (Guo et al., 2009).

\section{RDR3 - no functional information available}

\section{RDR4}

RDR4 has been linked to biogenesis of endogenous siRNAs (natsiRNAs) (Borges and Martienssen, 2015).

\section{RDR5 - no functional information obtained}

\section{RDR6}

RDR6 is necessary for sense-transgene mediated silencing and is important in antiviral defense against certain viruses (Beclin et al., 2002; Dalmay et al., 2000; Mourrain et al., 2000). RDR6-dependent antiviral response includes the cucumber mosaic virus in Arabidopsis (Wang et al., 2010) or tobacco mosaic virus in Nicotiana benthamina (Qu et al., 2005) but not the cauliflower mosaic virus in Arabidopsis (Blevins et al., 2011). RDR6 was also implicated in the biogenesis of tasiRNAs and development (Li et al., 2005a; Peragine et al., 2004; Vaucheret, 2005). RDR6-generated dsRNA is being processed by DCL4 (Howell et al., 2007; Qu et al., 2008).

\section{miRNA module}

\section{miRNA biogenesis}

Biogenesis initiates with recognition and cleavage of a primary miRNA (pri-miRNA), which is transcribed by polymerase II (Xie et al., 2010; Zhao et al., 2013). A plant pri-miRNA is a single-stranded RNA carrying a local hairpin structure. Many miRNAs in plants apparently originate from longer inverted repeats carrying sequences of their targets, which were generated by sequence duplications (Allen et al., 2004). These long inverted repeats subsequently eroded during evolution and only a short stem in the pri-miRNA persists as a functional remnant of the original long hairpin. The inverted repeat duplication hypothesis provides an explanation for the evolution of perfectly pairing miRNAs in plants. 
Plant miRNAs differ from animal miRNAs in several aspects. one of them is that they do not use a twostep nuclear-cytoplasmic process employing the nuclear Microprocessor complex with Drosha and cytoplasmic Dicer. Instead, plant miRNAs are produced in the nucleus in a two-step process involving a single Dicer protein - DCL1 (Fig. 3).

DCL1 requires additional cofactors, including DRB1/ HYL1 (a nuclear dsRNA binding protein (Vazquez et al., 2004)), HEN1 (HUA ENHANCER1, a small RNA methyltransferase (Yu et al., 2005)), SE (SERRATE, C2H2type zinc finger, (Lobbes et al., 2006; Yang et al., 2006)). DCL1 resides in a complex, in which physically interacts with DRB1 and HEN1 (Baranauske et al., 2015). DCL1, DRB1 and SE co-localize in the nucleus in so-called dicing bodies (D-bodies) (Fang and Spector, 2007). D-body function and assembly is not fully understood and there is a number of additional components which need to be functionally analyzed to unravel the complex connections between the D-body, signalling cascades, and responses to the environment (Reis et al., 2015a).

In the first step of miRNA biogenesis, DLC1 excises the miRNA/miRNA* duplex processing pri-miRNA from the base of the hairpin toward the loop (base-toloop) (Park et al., 2002; Reinhart et al., 2002). Loopto-base processing occurs in specific cases, such as miR159 and miR319 (Bologna et al., 2009). A unique case of bidirectional processing was observed for miR166, where it seems to play a regulatory role (Zhu et al., 2013). Plants also have non-canonical miRNAs, such as mirtrons, which skip the first cleavage step by

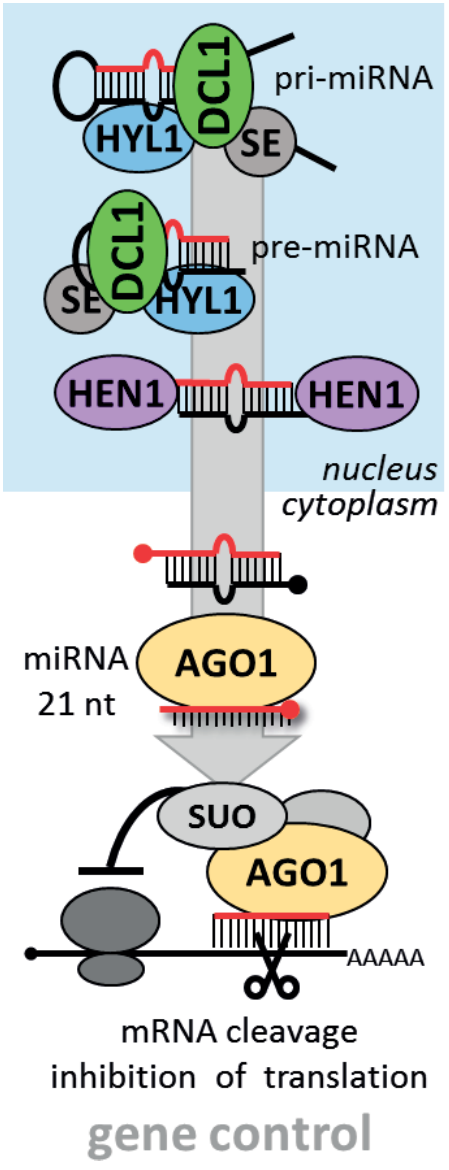

Figure 3 Plant miRNA pathway DCL1 (Meng and Shao, 2012).

The stem loop structure of pri-miRNA is recognized and processed by the DCL1DRB1-SE complex (Finnegan et al., 2003; Lobbes et al., 2006; Vazquez et al., 2004; Yang et al., 2006). Other DRB2 proteins (DRB2, 3, 5) also participate in biogenesis of miRNAs (Eamens et al., 2012a; Eamens et al., 2012b). Some pri-miRNA stems produce a single miRNA, some are longer and two or three additional ones on phase, i.e. require additional DCL1 cuts (Bologna et al., 2009; Zhang et al., 2010). Long hairpins can be processed by a diversity of Dicers to generate either miRNAs or siRNAs (Fig. 4). The subcellular location for dicing by DCL2 and DCL4, and subsequent AGO loading of the resulting siRNAs, is not completely understood (Axtell et al., 2011).

The 3' termini of the miRNA/miRNA* duplex are modified by HEN1 which adds a 2'-O-methyl group to the miRNA (Yu et al., 2005). This modification distinguishes plant miRNAs from animal miRNAs, which are not methylated (perhaps except of some minor 
population of miRNAs in arthropods (Horwich et al., 2007)). HEN1 was first identified genetically as a miRNA biogenesis co-factor, which was shown to localize into the nucleus (Park et al., 2002; Vaucheret et al., 2004; Vazquez et al., 2004). The HEN1 ortholog in rice was identified as WAF (WAVY LEAF), a crucial developmental factor (Abe et al., 2010). Structural analysis of HEN1 and its homologs showed that the catalytic domain of HEN1 is not closely related to any known RNA:2'-OH methyltransferases, but rather to small-molecule methyltransferases (Tkaczuk et al., 2006). One of the functions of the methylation is that it protects miRNAs from uridylation by an AGO1-associated uridylase that uridylates 5' RNA fragments generated by AGO1 cleavage (Li et al., 2005b; Ren et al., 2014).

miRNAs are exported from the nucleus with the assistance of hasty (HST), a plant homolog of Exportin 5 (Park et al., 2005). The subcellular location for dicing by DCL2 and DCL4, and subsequent AGO loading of the resulting siRNAs, is not yet clear. Loading of AGO1 with DCL1 products is assumed to take place in the cytoplasm (Axtell et al., 2011; Park et al., 2005). This loading onto AGO proteins involves sorting miRNAs according to the 5' terminal nucleotide and other factors (Mi et al., 2008; Montgomery et al., 2008; Zhu et al., 2011). Analysis of strand selection suggest that the strand with a lower 5 '-end thermostability is preferentially loaded into AGO1 (Eamens et al., 2009), which shows that plants employ the same loading asymmetry rule as animals. The selective loading of miRNA guide strand is directed by DRB1 (Eamens et al., 2009). DRB1 needs to be dephosphorylated for optimal activity; dephosphorylation is ensured by CPL1 (C-TERMINAL DOMAIN PHOSPHATASE-LIKE 1/FIERY2 (FRY2)) (Manavella et al., 2012). AGO1 miRISC loading also involves cyclophilin40 and HSP90; ATP hydrolysis by HSP helps to release the AGO1-miRNA complex (Earley and Poethig, 2011; Iki et al., 2012; Smith et al., 2009).

Plant miRNAs are mainly loaded onto AGO1, which has an endonuclease activity and is able to suppress gene expression through both target cleavage and translational inhibition (Baumberger and Baulcombe, 2005; Mourrain et al., 2000; Wu et al., 2009). AGO1 shows a preferential loading for miRNAs carrying uridine at their 5 ' end. A change in the 5 ' terminal nucleotide of an miRNA predictably redirects it into a different AGO complex and alters its biological activity (Mi et al., 2008). Remarkably, the DCL1 partnering with DRB1 or DRB2 will determine the mode of action of a loaded miRNA: DRB1 is associated with dicer cleavage while DRB2 with translational repression (Reis et al., 2015b). Interestingly, a subset of miRNAs is only $20 \mathrm{nt}$ long - their length appears to be determined by asymmetric bulges and mismatches at specific positions of the precursor (Lee et al., 2015).

\section{Modes of miRNA action in plant cells}

Similarly to animals, miRNAs loaded on AGO proteins serve as a guide for sequence-specific repression. Similarly to mammalian miRNAs, plant miRNAs can also mediate translational repression and sequence-specific cleavage of cognate mRNAs (e.g. (Beauclair et al., 2010; Brodersen et al., 2008; Li et al., 2014; Mallory and Bouche, 2008; Rhoades et al., 2002). At the same time, activities of plant mRNAs differ from their animal counterparts in several aspects. First, unlike animal miRNAs, many plant miRNAs frequently exhibit 


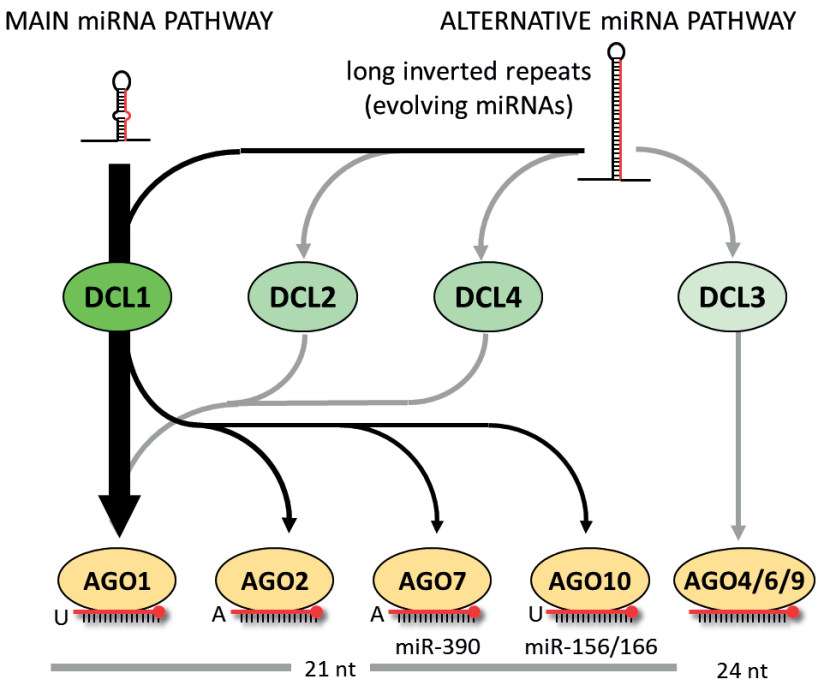

Figure 4 Overview of miRNA biogenesis and AGO loading The scheme summarizes the main and alternative miRNA biogenesis routes in plants; the alternative DCL2/3/4 processing routes are derived from (Axtell et al., 2011).

perfect or nearly perfect complementarity to their substrates resulting in RNAi-like cleavage of their targets (e.g. (Allen et al., 2004; Bowman, 2004; German et al., 2008; Kidner and Martienssen, 2004; Liu et al., 2014; Llave et al., 2002; Mallory et al., 2004; McHale and Koning, 2004; Rhoades et al., 2002; Xie et al., 2003). The high complementarity interactions are also easier to predict and this predictive value is being used for identification of putative plant miRNA targets. (Bonnet et al., 2010; Kumar et al., 2014; Rhoades et al., 2002; Shao et al., 2013). While animal miRNA binding sites are typically localized to 3'UTRs, plant miRNA recognition sites can be found in 5'UTRs, ORFs, or 3'UTRS as well as in non-coding RNAs (e.g. TAS3 RNA (Montgomery et al., 2008)). At the same time, functional features of miRNA binding are still incompletely understood as showed analysis of miR159 sites in MYB33/MYB65 (Li et al., 2014). Importantly, as mentioned above, the mode of miRNA action can be also influenced by a DRB partner during its biogenesis, i.e. independently of the target binding site (Reis et al., 2015b). Finally, plant miRNAs can also mediate transcriptional repression through RNA-dependent DNA methylation. This section will review all three types of miRNA-mediated repression.

\section{miRNA-mediated target cleavage}

miRNA-mediated target cleavage by AGO1 is a functionally important silencing mode as evidenced by the requirement of catalytically active AGO1 in agol mutant complementation experiments (Carbonell et al., 2012). AGO1, guided by a miRNA, cleaves in the middle of the base paired sequence (German et al., 2008; Llave et al., 2002). Similarly to other eukaryotes, exposing a free 5' fragment with a 3' hydroxyl and a 3' fragment with 
a 5' phosphate from a cleaved mRNA leads to decay, which involves a 5'-3' exonuclease (AtXrN4 in Arabidopsis), which attacks the 3' cleaved fragments (Souret et al., 2004). The 5 ' fragments are uridylated at 3 ' ends by HESO1 terminal uridylase; uridylation seem to be coupled with their final demise (Ren et al., 2014).

\section{miRNA-mediated translational inhibition}

Some plant miRNA:mRNA target base pairing could have central mismatches, preventing AGO-mediated cleavage. Other observations also suggest that plant miRNA-target interaction does not always result in AGO-catalyzed slicing but leads to translational repression (Axtell et al., 2006; Brodersen et al., 2008; Franco-Zorrilla et al., 2007; Li et al., 2013; Schwab et al., 2005). The molecular mechanism of miRNA-mediated translational repression in plants is less well understood than in animals. In any case, some similarities emerged. For example, AGO1 localizes to P-bodies, dynamic cytoplasmic foci containing many proteins involved in translational repression and mRNA degradation (Brodersen et al., 2008; Yang et al., 2012).

Another interesting factor, resembling GW182 bridging of target recognition and recruitment of mRNA degrading mechanisms, is SUO, which was identified through a mutation screen for factors contributing to miRNA-mediated repression (Yang et al., 2012). SUO encodes a large protein with N-terminal bromo-adjacent homology and transcription elongation factor S-II domains and, importantly, two C-terminal GW repeats (Yang et al., 2012). The SUO loss-of-function phenotype is a consequence of a defect in miRNA-mediated translational repression and it is reminiscent of plant phenotypes with reduced AGO1 activity (Yang et al., 2012). SUO is present in the nucleus, and co-localizes with DCP1 in the cytoplasm (Yang et al., 2012). An independent study of miRNA-mediated repression showed a functionally important link to decapping through the decapping component VARICOSE (VCS) (Ge-1 homolog), further suggesting that mechanisms underlying miRNA-mediated translational repression in animals and plants are related (Brodersen et al., 2008).

Another line of evidence linking AGO1 and GW-mediated recruitment of downstream repressing factors came from the analysis of viral inhibitors encoded by plant viruses the P1 protein from the Sweet potato mild mottle virus targets AGO1 and inhibits RISC activity through the N-terminal half containing region three WG/GW motifs (Giner et al., 2010).

\section{miRNA-mediated transcriptional silencing/DNA methylation}

In addition to the two usual post-transcriptional modes of action, plant miRNAs can be also plugged into the RNA-dependent DNA methylation mechanism. In this case, miRNA precursors would be processed by DCL3 into longer ( $24 \mathrm{nt})$ species and would be loaded onto AGO4/6/9 system (Axtell et al., 2011). A specific example of such miRNA has been discovered in rice where a class of miRNAs (denoted long miRNA, ImiRNAs) is processed by DCL3, loaded onto AGO4, and directs DNA methylation (Wu et al., 2010) (the molecular mechanism of RNA-dependent DNA methylation is described later). 


\section{Physiological roles of plant miRNAs}

Plant miRNAs have much more "focused" roles than animal miRNAs, in particular mammalian ones. This likely reflects their evolutionary origin, which is connected with their target genes, and the common slicing mode of action (discussed for example in (Svoboda and Cara, 2006)). Briefly, many plant miRNAs seem to originate from inverted repeats, which formed from sequences of their target genes, e.g. through duplication or recombination involving genes and pseudogenes. An interesting aspect of plant miRNA-mediated regulations is the targeting of various transcription factor families, which is translated phenotypic alterations. For example, during miRNA target prediction, of the 49 predicted targets, 34 were members of these transcription factor gene families involved in developmental patterning or cell differentiation (Rhoades et al., 2002). Validated miRNA-targeted transcription factor include the Class III HD-Zip gene family (Bowman, 2004), GRF transcription factors (Debernardi et al., 2014), Scarecrow-like (SCL) family of putative transcription factors (Llave et al., 2002) or MYB33/MYB65 (Li et al., 2014).

Mutants of miRNA factors yielded a whole array of phenotypes suggesting a number of different roles of miRNAs in cell proliferation (Debernardi et al., 2014; Debernardi et al., 2012; Rodriguez et al., 2010), plant development (Abe et al., 2010; Datta and Paul, 2015; Jover-Gil et al., 2012; Schauer et al., 2002), or in response to various physiological conditions, including environmental stress (Huang et al., 2009; Sunkar and Zhu, 2004). One of the notable features of plant miRNAs, which is analogous but distinct from circulating miRNAs in mammals, is that some plant miRNAs can cross cellular boundaries through plasmodesmata to adjacent cells (Marin-Gonzalez and Suarez-Lopez, 2012).

Interestingly, miRNA pathways in Arabidopsis are regulated by a negative feedback loop targeting DCL1 by miR162-guided mRNA cleavage (Xie et al., 2003). An analogous negative feedback loop was observed in Arabidopsis for AGO1, which is targeted by miR168 during development (Vaucheret et al., 2004).

\section{dsRNA-induced post-transcriptional silencing in PTGS \& VIG pathways}

The complexity of RNA silencing in plants comes from multiple layers, which are integrated to provide specific functions of specific small RNA pathway. These layers are (I) structural - e.g. processing of different types of substrates, sorting of small RNAs onto AGO proteins, and molecular effects - endonucleolytic cleavage, translational repression etc. (II) functional/conceptual - e.g. distinguishing between defensive mechanisms and physiological gene regulations, (III) spatiotemporal at multiple levels - including cellular compartmentalization, distinct genomic loci, parts of a plant or its life-cycle, differentiating between somatic and germ cells, leafs, flowering etc. This explains that despite four Dicer proteins, which produce two main classes of small RNAs (21/22 and $24 \mathrm{nt})$, there is over ten different names for AGO-bound small RNAs (Axtell, 2013; Borges and Martienssen, 2015), some of which were already mentioned: miRNA, ImiRNA, hp-siRNA, natsiRNA, cis-natsiRNA, trans-natsiRNA, tasiRNA, phasiRNA, easiRNA, hetsiRNA, diRNAs ... (Fig. 4). 


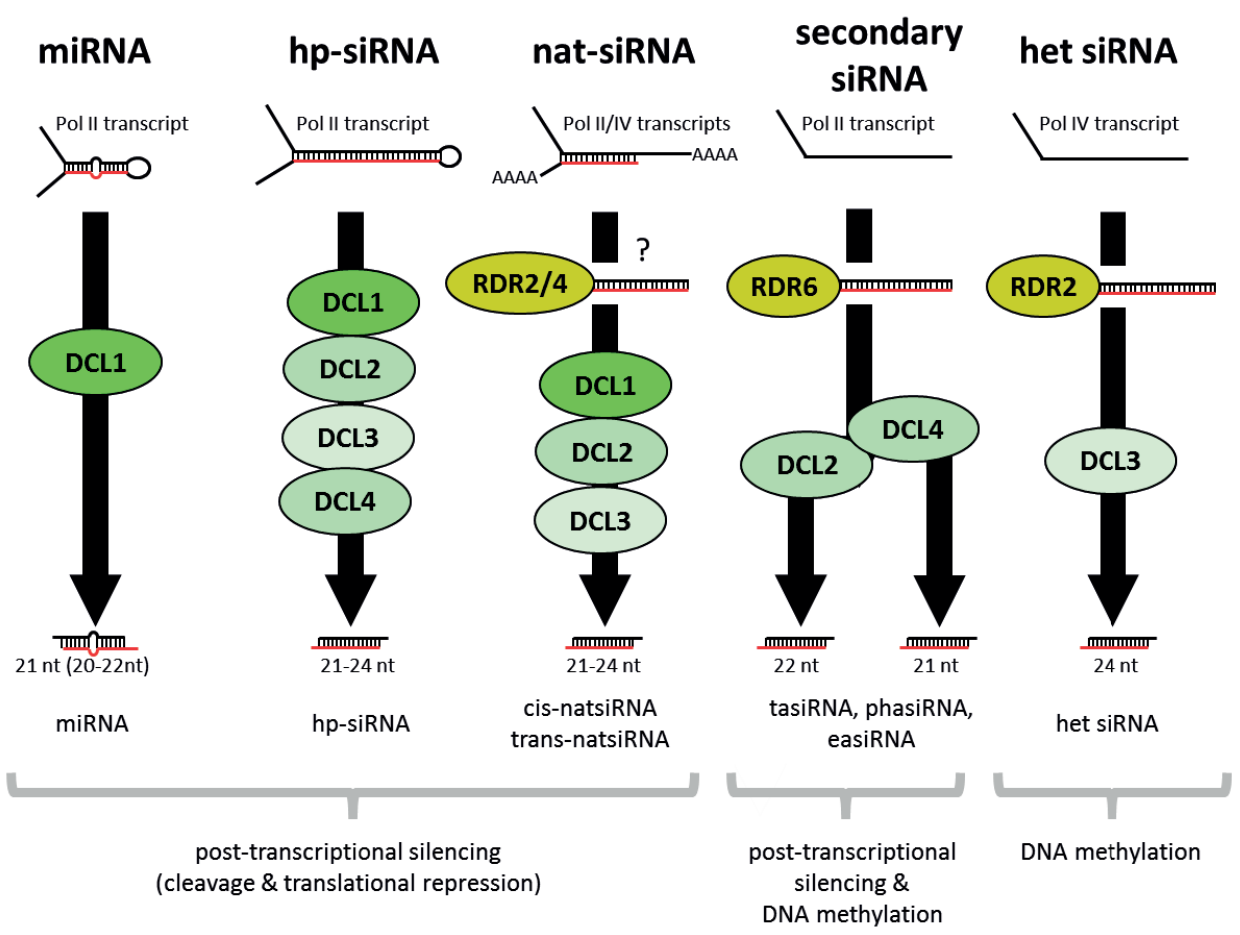

Figure 5 Complexity of small RNAs in plants. The scheme was adapted from (Borges and Martienssen, 2015)

However, while there is aseemingly unpenetrable thicket of substrates, DCLs, AGOs, RDRs, small RNAs, and biological effects, RNA silencing in plants is built from three main mechanistic modules. The three modules are (I) the miRNA module reviewed above, (II) the "RNAi" module, into which can be included dsRNA-induced post-transcriptional silencing in PTGS \& VIG pathways, and the (III) the transcriptional silencing RdDM module, which encompasses $24 \mathrm{nt}$ small RNA-driven de novo DNA methylation and associated chromatin changes and which will be discussed in the next section. This module will thus focus on long dsRNA processing into small RNAs, which is the key step in the dsRNA response.

Many different substrates give a rise to primary and secondary small RNAs that are 21/22 or $24 \mathrm{nt}$ long. Deep sequencing showed that plants have relative to other eukaryotes extraordinarily large and complex populations of small RNAs (Henderson et al., 2006; Howell et al., 2007; Kasschau et al., 2007; Lu et al., 2005; Rajagopalan et al., 2006). More than the half of the small RNAs are $24 \mathrm{nt}$ long "heterochromatic" siRNAs, which map to intergenic regions, particularly to the proximal and distal pericentromeric regions (Rajagopalan et al., 2006). Notably, plant small RNAs are typically methylated at the 2'-hydroxyl group of the 3 ' terminal nucleotide by the methylase HEN1 (Li et al., 2005b; Yu et al., 2005).

Structurally, the three main types of primary substrates for DCL proteins are short, miRNA-like hairpins, long dsRNA hairpins, and long dsRNA (e.g. formed during viral 
replication). In addition, activity of RDRs generates long dsRNA to produce either primary siRNAs (i.e. long dsRNA origin is more or less independent of AGO proteins activity) or secondary siRNAs, where an RDR converts an AGO-targeted transcript into dsRNA. In terms of silencing effects, AGO-loaded small RNAs can induce mRNA cleavage, translational repression, and de novo DNA methylation (RdDM). Biogenesis of small RNAs and the first two modes of action were described above, RdDM will be described in the next section. Thus, the rest of this section will provide an overview of the main routes of dsRNA synthesis and degradation involved in silencing (Fig. 4).

The main Dicer proteins producing small RNAs in the RNAi-like module are DCL2/3/4. All of them participate in antiviral response and in processing various other substrates, which were described above. Importantly, there is a hierarchical and functional separation of the three DCL proteins, such that small RNAs produced by DCL3 can be channelled into the RdDM module. DCL4 and DCL2 act hierarchically on viral and endogenous substrates. DCL4 seems to act earlier while DCL2 later. Both act in a loop involving DRD6, which amplifies the effect (Brosnan et al., 2007; Chen et al., 2011; Deleris et al., 2006; Di Serio et al., 2009; Garcia-Ruiz et al., 2010; Howell et al., 2007; Liu et al., 2007; Mlotshwa et al., 2008; Moissiard et al., 2007; Ogwok et al., 2016; Parent et al., 2015; Qu et al., 2008; Xie et al., 2005).

Small RNAs produced by DCL2/3/4 are sorted onto different AGO proteins, which execute the silencing and, eventually, mark cognate RNAs for RDR6 for amplification. Some of the sorting rules were described above. AGO4/6 accommodate longer $24 \mathrm{nt}$ small RNAs produced by DCL3 and can induce RdDM. Smaller RNAs are loaded onto other AGO proteins depending on the sorting rules and AGO availability - please, refer to the AGO section for more details.

\section{Systemic silencing}

RNAi in higher plants can be non-autonomous (Dunoyer et al., 2005; Himber et al., 2003). It was found that exogenous and endogenous DCL4-dependent $21 \mathrm{nt}$ siRNAs can act as mobile silencing signals between plant cells in a process which likely involves siRNA duplexes rather than loaded AGO1 proteins (Dunoyer et al., 2010). Follow up studies confirmed the core conclusions: graft transmission of endogenous siRNAs inducing silencing (Ali et al., 2013; Liang et al., 2012). The molecular mechanism of systemic RNAi through the vasculature is not completely understood. It seems that small RNAs are transported from cell to cell via plasmodesmata rather than diffusing from their source in the phloem (Liang et al., 2012).

\section{Transcriptional Gene Silencing}

RdDM was actually the first discovered small RNA-controlled epigenetic mechanism. It was originally found in tobacco plants where viroid cDNA, integrated into the genome, became specifically methylated in the presence of autonomous viroid RNA-RNA replication (Wassenegger et al., 1994). It was subsequently shown that as little as $30 \mathrm{bp}$ of targeted 


\section{transgene \& viral silencing}

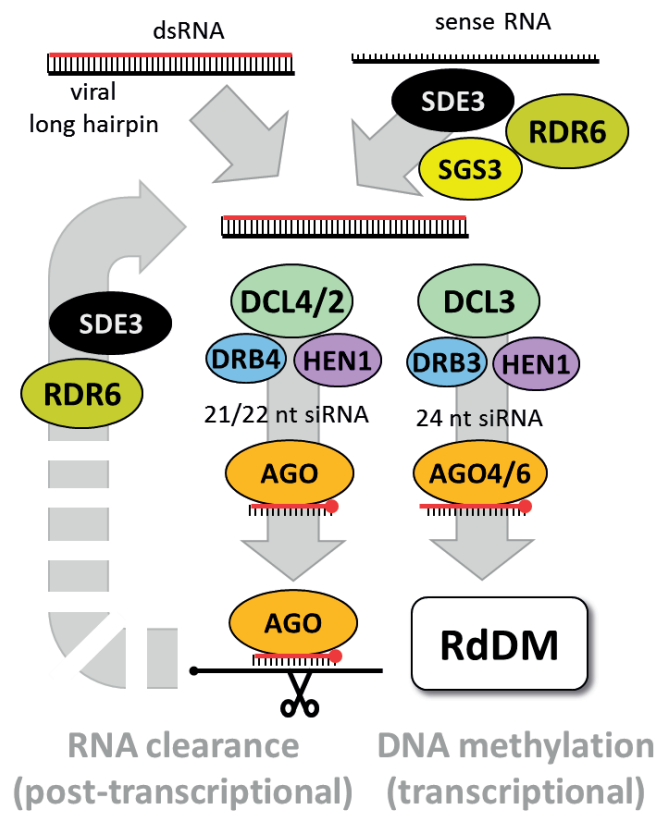

Figure 6 "RNAi module" of RNA silencing in Arabidopsis.

The key step in the RNAi module is conversion of dsRNA into small RNAs by one of the DCL proteins, among which dominate DCL2/3/4. However, DCL1 is also able to produce $21 \mathrm{nt}$ siRNAs from a transgenic inverted repeat (Papp et al., 2003). Various dsRNA substrates can enter the RNAi module. Some of them are produced by RDR6 either as the initial trigger or as an amplification step where AGO-targeted RNAs are converted to dsRNA, which is processed into secondary siRNAs. If the targeting by AGO is precisely defined (e.g. by miRNA), the secondary siRNAs would be phased. DCL3-generated 24 nt siRNAs can induce RdDM.

DNA is sufficient for RdDM and that dsRNA complementary to promoter region can induce promoter methylation and transcriptional silencing (Jones et al., 2001; Mette et al., 2000; Pelissier et al., 1999; Pelissier and Wassenegger, 2000; Thomas et al., 2001).

RdDM not only affects cytosine residues within canonical, symmetrical $\mathrm{CpG}$ dinucleotides, but also $\mathrm{CpNpG}$ and other non-CpG asymmetric targets (Aufsatz et al., 2002a; Pelissier et al., 1999). Since 21-24 nt small RNAs were produced from the original trigger (Mette et al., 2000), RdDM was recognized as one of RNA silencing pathways in plants.

The canonical RdDM pathway (Fig. 7) is initiated by plant-specific RNA polymerase Pol IV that produces single-stranded RNA transcripts from genomic loci to be silenced (Herr et al., 2005; Onodera et al., 2005). RNA transcripts are transported into the nucleolus where they are converted into dsRNA by RNA-dependent RNA polymerase RDR2 and processed by DCL3 into siRNAs, which are then methylated by the methylase HEN1. AGO4, DCL3, RDR2 and 24-nt siRNAs complementary to the heterochromatin regions co-localize in nucleolar processing centers ( $\mathrm{Li}$ et al., 2006; Pontes et al., 2006). Importantly, AGO4 is 
not the only AGO mediating RdDM, RdDM can be induced by AGO4, 6, and 9, which are functionally diverged, largely due to their differential expression (Havecker et al., 2010)

Processing centers are located at a distance from source/target loci and siRNAs trafficking between processing bodies and target regions has to take place. However, mechanisms regulating this process remains unknown at present. Nucleolus-associated so-called Cajal bodies are also centers for AGO1- and DCL1-dependent miRNA processing and are the sites of nonsense-mediated decay indicating closer relationship between RNAi-dependent and other RNA regulating pathways.

Methylated siRNAs associate with AGO4, which interacts with Pol V subunit NRPD1b and the complex moves into the nucleoplasm where it associates with NRPD2a and forms functional Pol V complex. In co-operation with de novo DNA methyltransferase DRM2, and SNF2-like chromatin remodelling protein DEFECTIVE IN RNA-DIRECTED DNA METHYLATION 1 (DRD1), the Pol V complex facilitates de novo DNA methylation of cytosines in all sequence contexts at the targeted locus (Kanno et al., 2005a; Kanno et al., 2005b; Kanno et al., 2004; Li et al., 2006; Pontes et al., 2006).

$\mathrm{CpG}$ methylation in the targeted locus is subsequently maintained during the replication by complexes containing DECREASE IN DNA METHYLATION 1 (DDM1) (Vongs et al., 1993), a maintenance DNA methyltransferase MET1 and histone deacetylase HDA6 (Aufsatz et al., 2004; Aufsatz et al., 2002b; Jones et al., 2001). Methylation at non-CpG nucleotides depends on DNA methyltransferase CHROMOMEHTYLASE3 (CMT3), de novo cytosine methyltransferases DRM1 and DRM2 (DOMAINS REARRANGED METHYLTRANSFERASE), Arabidopsis thaliana homologs of mammalian DNMT3, and a lysine 9 on histone 3 (H3K9) methyltransferase SUVH4/KRYPTONITE (Bartee et al., 2001; Cao and Jacobsen, 2002; Chan et al., 2004; Jackson et al., 2002; Lindroth et al., 2001). Notably, SUVH4 is dispensable for de novo DNA methylation and silencing (Jackson et al., 2002; Malagnac et al., 2002) suggesting that H3K9 methylation in plants does not precede DNA methylation. It has been speculated that the difference in mechanistic relationships between H3K9 methylation and DNA methylation in plants and other model organisms may perhaps reflect dependence and independence of RNA silencing and histone modifications in these models (Matzke and Birchler, 2005).

$\mathrm{RdDM}$ is induced by different types of sequences and has a number of targets. RdDM was studied using two types of dsRNA as inducers of methylation (a) transgenic hairpin constructs (Aufsatz et al., 2002a; Pelissier et al., 1999), and (b) dsRNA viruses (Hall et al., 2002; Vaistij et al., 2002). Notably, these two triggers elicit somewhat different responses. In contrast to the RdDM silencing induced by hairpin constructs, silencing induced by homologous viral transgenes can spread from the region of homology both upstream and downstream (Vaistij et al., 2002). This process depends on RNA-dependent RNA polymerase RDR6, a maintenance methyltransferase MET1, and AGO1 (Jones et al., 2001; Morel et al., 2002). Although histone modifications were not examined in the original paper of Vaistij et al., spreading of silencing resembles RNAi-dependent heterochromatin formation in Schizosaccharomyces pombe (Vaistij et al., 2002). In addition to these exogenous triggers, analysis of endogenous small RNAs and DNA methylation studies revealed that major targets of RdDM are transposons and repeats in constitutive and facultative heterochromatin but not all transposons are repressed by RdDM; only a limited number 


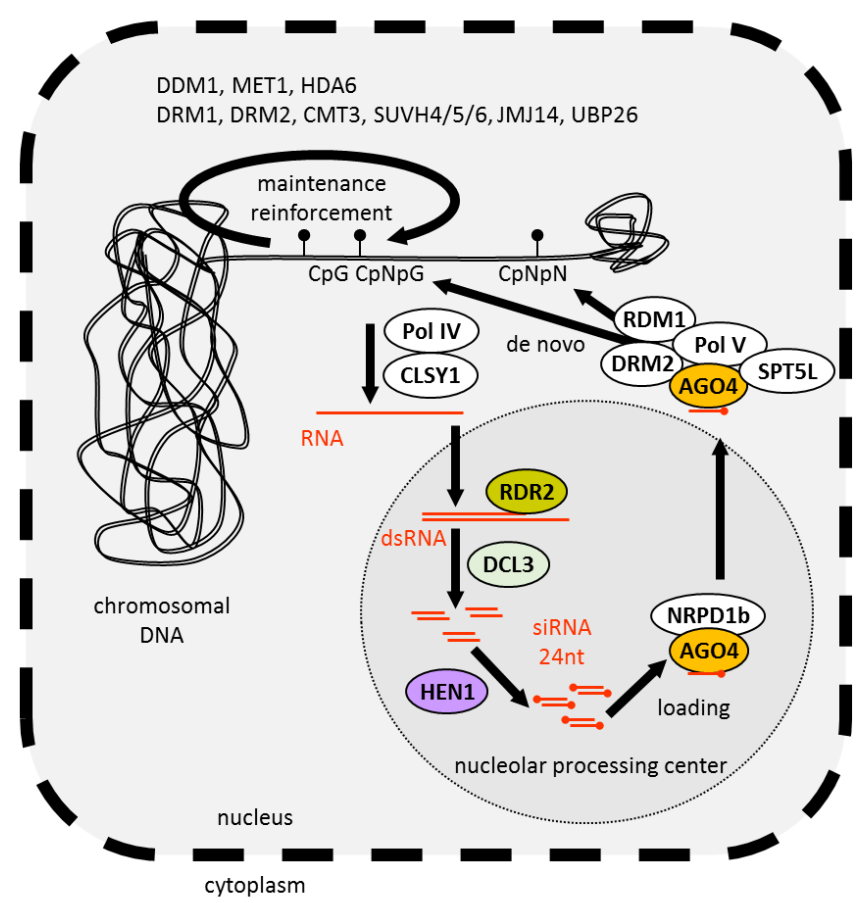

Figure 7 Schematic model of canonical RdDM in A. thaliana

Core components of RNA silencing are colored. Target locus is transcribed by RNA polymerase Pol IV into RNA, which is relocated into a nucleolar processing center where it is converted into dsRNA by RNA-dependent RNA polymerase RDR2 and further processed. Priming of RDR2 may involve cleavage of pol IV transcripts by an AGO protein (AGO4?). dsRNA is cleaved by DCL3 into siRNAs, which are methylated by the methylase HEN1. siRNAs are then loaded onto AGO4, which interacts with Pol $\checkmark$ subunit NRPD1b. The complex moves into the nucleoplasm and forms functional Pol V complex, which, in co-operation with de novo DNA methyltransferase DRM2, and SNF2-like chromatin remodelling protein DRD1, facilitates in a sequence-specific manner de novo DNA methylation of cytosines (black circles on a stalk) in all sequence contexts at homologous loci. Recognition of a target locus probably occurs via binding to an RNA from the silenced locus. CpG methylation is maintained during the replication by complexes containing DDM1, a maintenance DNA methyltransferase MET1, and histone deacetylase HDA6. Methylation at non-CpG nucleotides is dependent on DNA methyltransferase CMT3, de novo cytosine methyltransferases DRM1 and DRM2, and a H3K9 methyltransferase SUVH4/KRYPTONITE.

of targets of RdDM are endogenous genes (Borges and Martienssen, 2015). As RdDM can be reversed by demethylation (Penterman et al., 2007), a picture emerges in which RdDM is not only a repressive mechanism controlling repetitive and viral sequences but also a part of regulatory networks controlling gene expression, which includes other chromatin modifications.

In addition, there is a second RdDM pathway in flowering plants, designated non-canonical RdDM (Matzke et al., 2015), which is initiated by pol II transcripts, which are channeled through DCL3 and AGO4/6 in the "RNAi module" into RdDM (Fig. 8). 


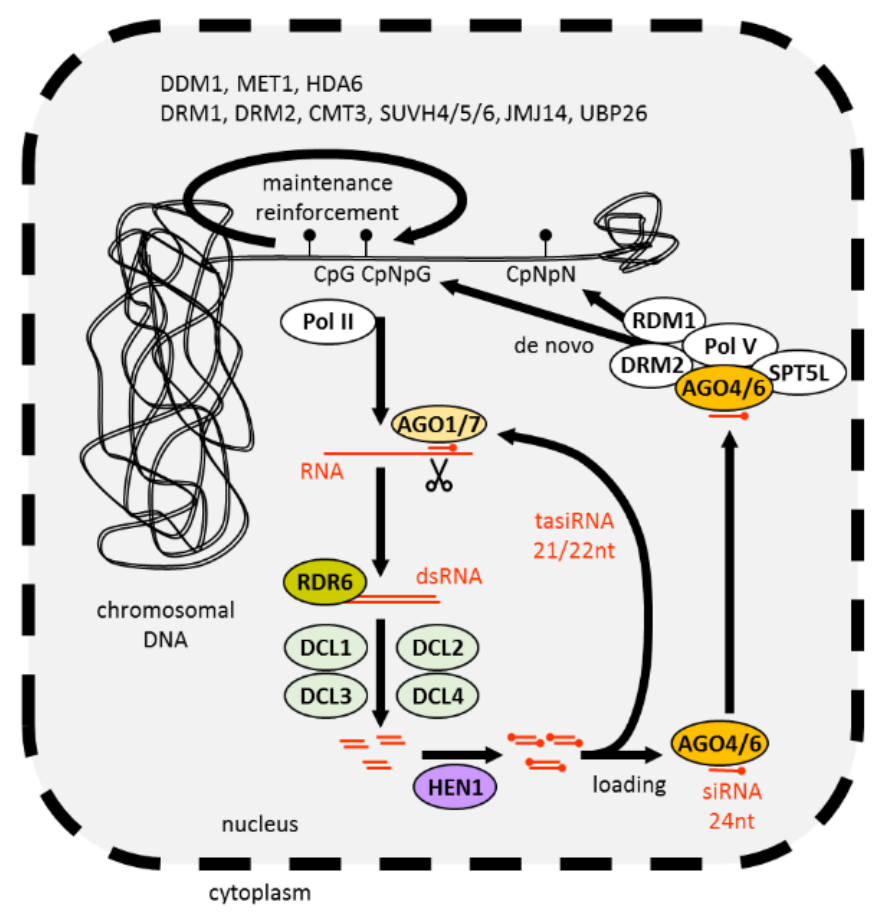

Figure 8 Schematic model of non-canonical RdDM in $A$. thaliana

The target/trigger locus is transcribed by RNA polymerase II into RNA, which is recognized by an AGO-loaded small RNA, is converted into dsRNA by RNA-dependent RNA polymerase RDR6, and it is processed by one of DCL proteins where AGO4/6 bound small RNAs can enter RdDM module, 21/22 nt small RNAs can operate within the RNAi module and amplify the silencing response.

\section{Acknowledgement}

I would like to thank my colleagues Jan Paces, Miloslav Nic, and Tomas Novotny for help with collecting literature for the review. The review content was produced under a contract OC/EFSA/GMO/2015/01-CT 01 with European Food Safety Authority (EFSA); the opinions expressed are those of the contractor only and do not represent EFSA's official position. Publication of the review was funded by LO1220 and LM2015063 by the Ministry of Education, Youth and Sports.

\section{References}

Abe, M., Yoshikawa, T., Nosaka, M., Sakakibara, H., Sato, Y., Nagato, Y., and Itoh, J. (2010). WAVY LEAF1, an Ortholog of Arabidopsis HEN1, Regulates Shoot Development by Maintaining MicroRNA and Trans-Acting Small Interfering RNA Accumulation in Rice. Plant Physiology $154,1335-1346$. 
Agorio, A., and Vera, P. (2007). ARGONAUTE4 is required for resistance to Pseudomonas syringae in Arabidopsis. Plant Cell 19, 3778-3790.

Akbergenov, R., Si-Ammour, A., Blevins, T., Amin, I., Kutter, C., Vanderschuren, H., Zhang, P., Gruissem, W., Meins, F., Hohn, T., et al. (2006). Molecular characterization of geminivirus-derived small RNAs in different plant species. Nucleic Acids Research 34, 462-471.

Ali, E., Kobayashi, K., Yamaoka, N., Ishikawa, M., and Nishiguchi, M. (2013). Graft transmission of RNA silencing to non-transgenic scions for conferring virus resistance in tobacco. Plos One 8 , e63257.

Allen, E., Xie, Z., Gustafson, A.M., Sung, G.H., Spatafora, J.W., and Carrington, J.C. (2004). Evolution of microRNA genes by inverted duplication of target gene sequences in Arabidopsis thaliana. Nature Genetics 36, 1282-1290.

Aregger, M., Borah, B.K., Seguin, J., Rajeswaran, R., Gubaeva, E.G., Zvereva, A.S., Windels, D., Vazquez, F., Blevins, T., Farinelli, L., et al. (2012). Primary and Secondary siRNAs in Geminivirus-induced Gene Silencing. Plos Pathogens 8, e1002941-e1002941.

Aufsatz, W., Mette, M.F., Matzke, A.J., and Matzke, M. (2004). The role of MET1 in RNA-directed de novo and maintenance methylation of CG dinucleotides. Plant Molecular Biology 54, 793-804.

Aufsatz, W., Mette, M.F., van der Winden, J., Matzke, A.J., and Matzke, M. (2002a). RNA-directed DNA methylation in Arabidopsis. Proc Natl Acad Sci U S A 99 Suppl 4, 16499-16506.

Aufsatz, W., Mette, M.F., van der Winden, J., Matzke, M., and Matzke, A.J. (2002b). HDA6, a putative histone deacetylase needed to enhance DNA methylation induced by double-stranded RNA. The EMBO journal 21, 6832-6841.

Axtell, M.J. (2013). Classification and comparison of small RNAs from plants. Annual review of plant biology 64, 137-159.

Axtell, M.J., Jan, C., Rajagopalan, R., and Bartel, D.P. (2006). A two-hit trigger for siRNA biogenesis in plants. Cell 127, 565-577.

Axtell, M.J., Westholm, J.O., and Lai, E.C. (2011). Vive la difference: biogenesis and evolution of microRNAs in plants and animals. Genome Biology 12, 221.

Bai, M., Yang, G.-S., Chen, W.-T., Mao, Z.-C., Kang, H.-X., Chen, G.-H., Yang, Y.-H., and Xie, B.-Y. (2012). Genome-wide identification of Dicer-like, Argonaute and RNA-dependent RNA polymerase gene families and their expression analyses in response to viral infection and abiotic stresses in Solanum lycopersicum. Gene 501, 52-62.

Baranauske, S., Mickute, M., Plotnikova, A., Finke, A., Venclovas, C., Klimasauskas, S., and Vilkaitis, G. (2015). Functional mapping of the plant small RNA methyltransferase: HEN1 physically interacts with HYL1 and DICER-LIKE 1 proteins. Nucleic Acids Research 43, 2802-2812.

Bartee, L., Malagnac, F., and Bender, J. (2001). Arabidopsis cmt3 chromomethylase mutations block non-CG methylation and silencing of an endogenous gene. Genes Dev 15, 1753-1758.

Baumberger, N., and Baulcombe, D.C. (2005). Arabidopsis ARGONAUTE1 is an RNA Slicer that selectively recruits microRNAs and short interfering RNAs. Proc Natl Acad Sci U S A 102, 11928-11933.

Beauclair, L., Yu, A., and Bouche, N. (2010). microRNA-directed cleavage and translational repression of the copper chaperone for superoxide dismutase mRNA in Arabidopsis. Plant Journal 62, 454-462.

Beclin, C., Boutet, S., Waterhouse, P., and Vaucheret, H. (2002). A branched pathway for transgene-induced RNA silencing in plants. Current Biology 12, 684-688. 
Blevins, T., Rajeswaran, R., Aregger, M., Borah, B.K., Schepetilnikov, M., Baerlocher, L., Farinelli, L., Meins, F., Hohn, T., and Pooggin, M.M. (2011). Massive production of small RNAs from a non-coding region of Cauliflower mosaic virus in plant defense and viral counter-defense. Nucleic Acids Research 39, 5003-5014.

Bohmert, K., Camus, I., Bellini, C., Bouchez, D., Caboche, M., and Benning, C. (1998). AGO1 defines a novel locus of Arabidopsis controlling leaf development. The EMBO journal 17, 170-180.

Bologna, N.G., Mateos, J.L., Bresso, E.G., and Palatnik, J.F. (2009). A loop-to-base processing mechanism underlies the biogenesis of plant microRNAs miR319 and miR159. The EMBO journal 28, 3646-3656.

Bologna, N.G., and Voinnet, O. (2014). The Diversity, Biogenesis, and Activities of Endogenous Silencing Small RNAs in Arabidopsis. In Annual Review of Plant Biology, Vol 65, pp. 473-503.

Bonnet, E., He, Y., Billiau, K., and Van de Peer, Y. (2010). TAPIR, a web server for the prediction of plant microRNA targets, including target mimics. Bioinformatics 26, 1566-1568.

Bonnet, E., Van de Peer, Y., and Rouze, P. (2006). The small RNA world of plants. New Phytologist $171,451-468$.

Borges, F., and Martienssen, R.A. (2015). The expanding world of small RNAs in plants. Nature Reviews Molecular Cell Biology 16, 727-741.

Bouche, N., Lauressergues, D., Gasciolli, V., and Vaucheret, H. (2006). An antagonistic function for Arabidopsis DCL2 in development and a new function for DCL4 in generating viral siRNAs. The EMBO journal 25, 3347-3356.

Bowman, J.L. (2004). Class III HD-Zip gene regulation, the golden fleece of ARGONAUTE activity? Bioessays 26, 938-942.

Boyko, A., and Kovalchuk, I. (2010). Transgenerational response to stress in Arabidopsis thaliana. Plant Signaling and Behavior 5, 995-998.

Bozorov, T.A., Pandey, S.P., Dinh, S.T., Kim, S.G., Heinrich, M., Gase, K., and Baldwin, I.T. (2012). DICER-like Proteins and Their Role in Plant-herbivore Interactions in Nicotiana attenuata. Journal of Integrative Plant Biology 54, 189-206.

Brandt, R., Xie, Y.K., Musielak, T., Graeff, M., Stierhof, Y.D., Huang, H., Liu, C.M., and Wenkel, S. (2013). Control of stem cell homeostasis via interlocking microRNA and microProtein feedback loops. Mechanisms of Development 130, 25-33.

Brodersen, P., Sakvarelidze-Achard, L., Bruun-Rasmussen, M., Dunoyer, P., Yamamoto, Y.Y., Sieburth, L., and Voinnet, O. (2008). Widespread translational inhibition by plant miRNAs and siRNAs. Science 320, 1185-1190.

Brosnan, C.A., Mitter, N., Christie, M., Smith, N.A., Waterhouse, P.M., and Carroll, B.J. (2007). Nuclear gene silencing directs reception of long-distance mRNA silencing in Arabidopsis. Proc Natl Acad Sci U S A 104, 14741-14746.

Brosseau, C., and Moffett, P. (2015). Functional and Genetic Analysis Identify a Role for Arabidopsis ARGONAUTE5 in Antiviral RNA Silencing. Plant Cell 27, 1742-1754.

Cao, M.J., Du, P., Wang, X.B., Yu, Y.Q., Qiu, Y.H., Li, W.X., Gal-On, A., Zhou, C.Y., Li, Y., and Ding, S.W. (2014). Virus infection triggers widespread silencing of host genes by a distinct class of endogenous siRNAs in Arabidopsis. Proc Natl Acad Sci U S A 111, 14613-14618.

Cao, X., and Jacobsen, S.E. (2002). Role of the arabidopsis DRM methyltransferases in de novo DNA methylation and gene silencing. Current Biology 12, 1138-1144. 
Carbonell, A., and Carrington, J.C. (2015). Antiviral roles of plant ARGONAUTES. Current Opinion in Plant Biology 27, 111-117.

Carbonell, A., Fahlgren, N., Garcia-Ruiz, H., Gilbert, K.B., Montgomery, T.A., Nguyen, T., Cuperus, J.T., and Carrington, J.C. (2012). Functional Analysis of Three Arabidopsis ARGONAUTES Using Slicer-Defective Mutants. Plant Cell 24, 3613-3629.

Chan, S.W., Zilberman, D., Xie, Z., Johansen, L.K., Carrington, J.C., and Jacobsen, S.E. (2004). RNA silencing genes control de novo DNA methylation. Science 303, 1336.

Chellappan, P., Xia, J., Zhou, X.F., Gao, S., Zhang, X.M., Coutino, G., Vazquez, F., Zhang, W.X., and Jin, H.L. (2010). siRNAs from miRNA sites mediate DNA methylation of target genes. Nucleic Acids Research 38, 6883-6894.

Chen, D.J., Meng, Y.J., Yuan, C.H., Bai, L., Huang, D.L., Lv, S.L., Wu, P., Chen, L.L., and Chen, M. (2011). Plant siRNAs from introns mediate DNA methylation of host genes. RNA 17, 1012-1024.

Chen, X.M. (2009). Small RNAs and Their Roles in Plant Development. In Annual Review of Cell and Developmental Biology, pp. 21-44.

Clavel, M., Pelissier, T., Descombin, J., Jean, V., Picart, C., Charbonel, C., Saez-Vasquez, J., Bousquet-Antonelli, C., and Deragon, J.-M. (2015). Parallel action of AtDRB2 and RdDM in the control of transposable element expression. BMC Plant Biology 15, 455-455.

Clavel, M., Pelissier, T., Montavon, T., Tschopp, M.A., Pouch-Pelissier, M.N., Descombin, J., Jean, V., Dunoyer, P., Bousquet-Antonelli, C., and Deragon, J.M. (2016). Evolutionary history of double-stranded RNA binding proteins in plants: identification of new cofactors involved in easiRNA biogenesis. Plant Molecular Biology 91, 131-147.

Coruh, C., Cho, S.H., Shahid, S., Liu, Q.K., Wierzbicki, A., and Axtella, M.J. (2015). Comprehensive Annotation of Physcomitrella patens Small RNA Loci Reveals That the Heterochromatic Short Interfering RNA Pathway Is Largely Conserved in Land Plants. Plant Cell 27, 2148-2162.

Curtin, S.J., Kantar, M.B., Yoon, H.W., Whaley, A.M., Schlueter, J.A., and Stupar, R.M. (2012). Co-expression of soybean Dicer-like genes in response to stress and development. Functional \& Integrative Genomics 12, 671-682.

Curtin, S.J., Watson, J.M., Smith, N.A., Eamens, A.L., Blanchard, C.L., and Waterhouse, P.M. (2008). The roles of plant dsRNA-binding proteins in RNAi-like pathways. FEBS Letters 582, 2753-2760.

Dalmay, T., Hamilton, A., Rudd, S., Angell, S., and Baulcombe, D.C. (2000). An RNA-dependent RNA polymerase gene in Arabidopsis is required for posttranscriptional gene silencing mediated by a transgene but not by a virus. Cell 101, 543-553.

Datta, R., and Paul, S. (2015). Plant microRNAs: master regulator of gene expression mechanism. Cell Biology International 39, 1185-1190.

Daxinger, L., Kanno, T., Bucher, E., van der Winden, J., Naumann, U., Matzke, A.J.M., and Matzke, M. (2009). A stepwise pathway for biogenesis of 24-nt secondary siRNAs and spreading of DNA methylation. The EMBO journal 28, 48-57.

Debernardi, J.M., Mecchia, M.A., Vercruyssen, L., Smaczniak, C., Kaufmann, K., Inze, D., Rodriguez, R.E., and Palatnik, J.F. (2014). Post-transcriptional control of GRF transcription factors by microRNA miR396 and GIF co-activator affects leaf size and longevity. Plant Journal 79, 413-426.

Debernardi, J.M., Rodriguez, R.E., Mecchia, M.A., and Palatnik, J.F. (2012). Functional specialization of the plant miR396 regulatory network through distinct microRNA-target interactions. Plos Genetics 8, e1002419. 
Deleris, A., Gallego-Bartolome, J., Bao, J.S., Kasschau, K.D., Carrington, J.C., and Voinnet, O. (2006). Hierarchical action and inhibition of plant Dicer-like proteins in antiviral defense. Science 313, 68-71.

Di Serio, F., Gisel, A., Navarro, B., Delgado, S., de Alba, A.-E.M., Donvito, G., and Flores, R. (2009). Deep Sequencing of the Small RNAs Derived from Two Symptomatic Variants of a Chloroplastic Viroid: Implications for Their Genesis and for Pathogenesis. Plos One 4, e7539-e7539.

Diaz-Pendon, J.A., Li, F., Li, W.X., and Ding, S.W. (2007). Suppression of antiviral silencing by cucumber mosaic virus $2 \mathrm{~b}$ protein in Arabidopsis is associated with drastically reduced accumulation of three classes of viral small interfering RNAs. Plant Cell 19, 2053-2063.

Dolgosheina, E.V., Morin, R.D., Aksay, G., Sahinalp, S.C., Magrini, V., Mardis, E.R., Mattsson, J., and Unrau, P.J. (2008). Conifers have a unique small RNA silencing signature. RNA 14, 1508-1515.

Donaire, L., Barajas, D., Martinez-Garcia, B., Martinez-Priego, L., Pagan, I., and Llave, C. (2008). Structural and genetic requirements for the biogenesis of tobacco rattle virus-derived small interfering RNAs. Journal of Virology 82, 5167-5177.

Douglas, R.N., Wiley, D., Sarkar, A., Springer, N., Timmermans, M.C.P., and Scanlon, M.J. (2010). ragged seedling2 Encodes an ARGONAUTE7-Like Protein Required for Mediolateral Expansion, but Not Dorsiventrality, of Maize Leaves. Plant Cell 22, 1441-1451.

Dunoyer, P., Himber, C., and Voinnet, O. (2005). DICER-LIKE 4 is required for RNA interference and produces the 21 -nucleotide small interfering RNA component of the plant cell-to-cell silencing signal. Nature Genetics 37, 1356-1360.

Dunoyer, P., Schott, G., Himber, C., Meyer, D., Takeda, A., Carrington, J.C., and Voinnet, O. (2010). Small RNA Duplexes Function as Mobile Silencing Signals Between Plant Cells. Science 328, 912-916.

Eamens, A.L., Kim, K.W., Curtin, S.J., and Waterhouse, P.M. (2012a). DRB2 Is Required for MicroRNA Biogenesis in Arabidopsis thaliana. Plos One 7, e35933-e35933.

Eamens, A.L., Smith, N.A., Curtin, S.J., Wang, M.B., and Waterhouse, P.M. (2009). The Arabidopsis thaliana double-stranded RNA binding protein DRB1 directs guide strand selection from microRNA duplexes. RNA 15, 2219-2235.

Eamens, A.L., Wook Kim, K., and Waterhouse, P.M. (2012b). DRB2, DRB3 and DRB5 function in a non-canonical microRNA pathway in Arabidopsis thaliana. Plant Signaling and Behavior 7, 1224-1229.

Earley, K.W., and Poethig, R.S. (2011). Binding of the cyclophilin 40 ortholog SQUINT to Hsp90 protein is required for SQUINT function in Arabidopsis. Journal of Biological Chemistry 286, 38184-38189.

Eun, C., Lorkovic, Z.J., Naumann, U., Long, Q., Havecker, E.R., Simon, S.A., Meyers, B.C., Matzke, A.J.M., and Matzke, M. (2011). AGO6 Functions in RNA-Mediated Transcriptional Gene Silencing in Shoot and Root Meristems in Arabidopsis thaliana. Plos One 6, e25730-e25730.

Fang, Y., and Spector, D.L. (2007). Identification of nuclear dicing bodies containing proteins for microRNA biogenesis in living Arabidopsis plants. Current Biology 17, 818-823.

Fatyol, K., Ludman, M., and Burgyan, J. (2016). Functional dissection of a plant Argonaute. Nucleic Acids Research 44, 1384-1397.

Finnegan, E.J., Margis, R., and Waterhouse, P.M. (2003). Posttranscriptional gene silencing is not compromised in the Arabidopsis CARPEL FACTORY (DICER-LIKE1) mutant, a homolog of dicer-1 from Drosophila. Current Biology 13, 236-240. 
Franco-Zorrilla, J.M., Valli, A., Todesco, M., Mateos, I., Puga, M.I., Rubio-Somoza, I., Leyva, A., Weigel, D., Garcia, J.A., and Paz-Ares, J. (2007). Target mimicry provides a new mechanism for regulation of microRNA activity. Nature Genetics 39, 1033-1037.

Fusaro, A.F., Matthew, L., Smith, N.A., Curtin, S.J., Dedic-Hagan, J., Ellacott, G.A., Watson, J.M., Wang, M.B., Brosnan, C., Carroll, B.J., et al. (2006). RNA interference-inducing hairpin RNAs in plants act through the viral defence pathway. EMBO Rep 7, 1168-1175.

Galun, E. (2005). RNA silencing in plants. In Vitro Cellular \& Developmental Biology-Plant 41, $113-123$.

Garcia-Ruiz, H., Takeda, A., Chapman, E.J., Sullivan, C.M., Fahlgren, N., Brempelis, K.J., and Carrington, J.C. (2010). Arabidopsis RNA-Dependent RNA Polymerases and Dicer-Like Proteins in Antiviral Defense and Small Interfering RNA Biogenesis during Turnip Mosaic Virus Infection. Plant Cell 22, 481-496.

Garcia, D., Collier, S.A., Byrne, M.E., and Martienssen, R.A. (2006). Specification of leaf polarity in Arabidopsis via the trans-acting siRNA pathway. Current Biology 16, 933-938.

German, M.A., Pillay, M., Jeong, D.H., Hetawal, A., Luo, S., Janardhanan, P., Kannan, V., Rymarquis, L.A., Nobuta, K., German, R., et al. (2008). Global identification of microRNA-target RNA pairs by parallel analysis of RNA ends. Nature Biotechnology 26, 941-946.

Giner, A., Lakatos, L., Garcia-Chapa, M., Lopez-Moya, J.J., and Burgyan, J. (2010). Viral Protein Inhibits RISC Activity by Argonaute Binding through Conserved WG/GW Motifs. Plos Pathogens 6, 1-13.

Guo, X.Y., Zhang, Z.L., Gerstein, M.B., and Zheng, D.Y. (2009). Small RNAs Originated from Pseudogenes: cis- or trans-Acting? Plos Computational Biology 5, e1000449-e1000449.

Hall, I.M., Shankaranarayana, G.D., Noma, K., Ayoub, N., Cohen, A., and Grewal, S.I. (2002). Establishment and maintenance of a heterochromatin domain. Science 297, 2232-2237.

Havecker, E.R., Wallbridge, L.M., Hardcastle, T.J., Bush, M.S., Kelly, K.A., Dunn, R.M., Schwach, F., Doonan, J.H., and Baulcombe, D.C. (2010). The Arabidopsis RNA-Directed DNA Methylation Argonautes Functionally Diverge Based on Their Expression and Interaction with Target Loci. Plant Cell 22, 321-334.

He, X.J., Hsu, Y.F., Zhu, S.H., Wierzbicki, A.T., Pontes, O., Pikaard, C.S., Liu, H.L., Wang, C.S., Jin, H.L., and Zhu, J.K. (2009). An Effector of RNA-Directed DNA Methylation in Arabidopsis Is an ARGONAUTE 4-and RNA-Binding Protein. Cell 137, 498-508.

Henderson, I.R., Zhang, X., Lu, C., Johnson, L., Meyers, B.C., Green, P.J., and Jacobsen, S.E. (2006). Dissecting Arabidopsis thaliana DICER function in small RNA processing, gene silencing and DNA methylation patterning. Nature Genetics 38, 721-725.

Herr, A.J., Jensen, M.B., Dalmay, T., and Baulcombe, D.C. (2005). RNA polymerase IV directs silencing of endogenous DNA. Science 308, 118-120.

Himber, C., Dunoyer, P., Moissiard, G., Ritzenthaler, C., and Voinnet, O. (2003). Transitivity-dependent and -independent cell-to-cell movement of RNA silencing. The EMBO journal 22, 4523-4533.

Horwich, M.D., Li, C.J., Matranga, C., Vagin, V., Farley, G., Wang, P., and Zamore, P.D. (2007). The Drosophila RNA methyltransferase, DmHen1, modifies germline piRNAs and single-stranded siRNAs in RISC. Current Biology 17, 1265-1272.

Howell, M.D., Fahlgren, N., Chapman, E.J., Cumbie, J.S., Sullivan, C.M., Givan, S.A., Kasschau, K.D., and Carrington, J.C. (2007). Genome-wide analysis of the RNA-DEPENDENT RNA POLYMERASE6/DICER-LIKE4 pathway in Arabidopsis reveals dependency on miRNA- and tasiRNA-directed targeting. Plant Cell 19, 926-942. 
Huang, S.Q., Peng, J., Qiu, C.X., and Yang, Z.M. (2009). Heavy metal-regulated new microRNAs from rice. Journal of inorganic biochemistry 103, 282-287.

Hunter, C., Sun, H., and Poethig, R.S. (2003). The Arabidopsis heterochronic gene ZIPPY is an ARGONAUTE family member. Current Biology 13, 1734-1739.

Iki, T., Yoshikawa, M., Meshi, T., and Ishikawa, M. (2012). Cyclophilin 40 facilitates HSP90-mediated RISC assembly in plants. The EMBO journal 31, 267-278.

Jackson, J.P., Lindroth, A.M., Cao, X., and Jacobsen, S.E. (2002). Control of CpNpG DNA methylation by the KRYPTONITE histone H3 methyltransferase. Nature 416, 556-560.

Jakubiec, A., Yang, S.W., and Chua, N.H. (2012). Arabidopsis DRB4 protein in antiviral defense against Turnip yellow mosaic virus infection. Plant Journal 69, 14-25.

Jaskiewicz, L., and Filipowicz, W. (2008). Role of Dicer in posttranscriptional RNA silencing. Current topics in microbiology and immunology 320, 77-97.

Jaubert, M., Bhattacharjee, S., Mello, A.F.S., Perry, K.L., and Moffett, P. (2011). ARGONAUTE2 Mediates RNA-Silencing Antiviral Defenses against Potato virus X in Arabidopsis. Plant Physiology 156, 1556-1564.

Jeong, D.H., Thatcher, S.R., Brown, R.S.H., Zhai, J.X., Park, S., Rymarquis, L.A., Meyers, B.C., and Green, P.J. (2013). Comprehensive Investigation of MicroRNAs Enhanced by Analysis of Sequence Variants, Expression Patterns, ARGONAUTE Loading, and Target Cleavage. Plant Physiology 162, 1225-1245.

Ji, L.J., Liu, X.G., Yan, J., Wang, W.M., Yumul, R.E., Kim, Y.J., Dinh, T.T., Liu, J., Cui, X., Zheng, B.L., et al. (2011). ARGONAUTE10 and ARGONAUTE1 Regulate the Termination of Floral Stem Cells through Two MicroRNAs in Arabidopsis. Plos Genetics 7, e1001358-e1001358.

Jones, L., Keining, T., Eamens, A., and Vaistij, F.E. (2006). Virus-induced gene silencing of Argonaute genes in Nicotiana benthamiana demonstrates that extensive systemic silencing requires Argonaute1-like and Argonaute4-like genes. Plant Physiology 141, 598-606.

Jones, L., Ratcliff, F., and Baulcombe, D.C. (2001). RNA-directed transcriptional gene silencing in plants can be inherited independently of the RNA trigger and requires Met1 for maintenance. Current Biology 11, 747-757.

Jover-Gil, S., Candela, H., Robles, P., Aguilera, V., Barrero, J.M., Micol, J.L., and Ponce, M.R. (2012). The MicroRNA Pathway Genes AGO1, HEN1 and HYL1 Participate in Leaf Proximal-Distal, Venation and Stomatal Patterning in Arabidopsis. Plant and Cell Physiology 53, 1322-1333.

Kanno, T., Aufsatz, W., Jaligot, E., Mette, M.F., Matzke, M., and Matzke, A.J. (2005a). A SNF2-like protein facilitates dynamic control of DNA methylation. EMBO Rep 6, 649-655.

Kanno, T., Huettel, B., Mette, M.F., Aufsatz, W., Jaligot, E., Daxinger, L., Kreil, D.P., Matzke, M., and Matzke, A.J. (2005b). Atypical RNA polymerase subunits required for RNA-directed DNA methylation. Nature Genetics 37, 761-765.

Kanno, T., Mette, M.F., Kreil, D.P., Aufsatz, W., Matzke, M., and Matzke, A.J. (2004). Involvement of putative SNF2 chromatin remodeling protein DRD1 in RNA-directed DNA methylation. Current Biology 14, 801-805.

Kapoor, M., Arora, R., Lama, T., Nijhawan, A., Khurana, J.P., Tyagi, A.K., and Kapoor, S. (2008). Genome-wide identification, organization and phylogenetic analysis of Dicer-like, Argonaute and RNA-dependent RNA Polymerase gene families and their expression analysis during reproductive development and stress in rice. BMC Genomics 9, 451-451. 
Kasschau, K.D., Fahlgren, N., Chapman, E.J., Sullivan, C.M., Cumbie, J.S., Givan, S.A., and Carrington, J.C. (2007). Genome-wide profiling and analysis of Arabidopsis siRNAs. Plos Biology 5, e57.

Kidner, C.A., and Martienssen, R.A. (2004). Spatially restricted microRNA directs leaf polarity through ARGONAUTE1. Nature 428, 81-84.

Komiya, R., Ohyanagi, H., Niihama, M., Watanabe, T., Nakano, M., Kurata, N., and Nonomura, K. (2014). Rice germline-specific Argonaute MEL1 protein binds to phasiRNAs generated from more than 700 lincRNAs. Plant Journal 78, 385-397.

Kozomara, A., and Griffiths-Jones, S. (2014). miRBase: annotating high confidence microRNAs using deep sequencing data. Nucleic Acids Res 42, D68-73.

Kravchik, M., Damodharan, S., Stav, R., and Arazi, T. (2014a). Generation and characterization of a tomato DCL3-silencing mutant. Plant Science 221, 81-89.

Kravchik, M., Sunkar, R., Damodharan, S., Stav, R., Zohar, M., Isaacson, T., and Arazi, T. (2014b). Global and local perturbation of the tomato microRNA pathway by a trans-activated DICER-LIKE 1 mutant. Journal of Experimental Botany 65, 725-739.

Kumar, S.P., Pandya, H.A., and Jasrai, Y.T. (2014). A computational model for non-conserved mature miRNAs from the rice genome. Sar and Qsar in Environmental Research 25, 205-220.

Lee, W.C., Lu, S.H., Lu, M.H., Yang, C.J., Wu, S.H., and Chen, H.M. (2015). Asymmetric bulges and mismatches determine 20-nt microRNA formation in plants. RNA Biology 12, 1054-1066.

Leibman, D., Wolf, D., Saharan, V., Zelcer, A., Arazi, T., Yoel, S., Gaba, V., and Gal-On, A. (2011). A High Level of Transgenic Viral Small RNA Is Associated with Broad Potyvirus Resistance in Cucurbits. Molecular Plant-Microbe Interactions 24, 1220-1238.

Li, C.F., Pontes, O., El-Shami, M., Henderson, I.R., Bernatavichute, Y.V., Chan, S.W., Lagrange, T., Pikaard, C.S., and Jacobsen, S.E. (2006). An ARGONAUTE4-containing nuclear processing center colocalized with Cajal bodies in Arabidopsis thaliana. Cell 126, 93-106.

Li, H., Xu, L., Wang, H., Yuan, Z., Cao, X.F., Yang, Z.N., Zhang, D.B., Xu, Y.Q., and Huang, H. (2005a). The putative RNA-dependent RNA polymerase RDR6 acts synergistically with ASYMMETRIC LEAVES1 and 2 to repress BREVIPEDICELLUS and MicroRNA165/166 in Arabidopsis leaf development. Plant Cell 17, 2157-2171.

Li, J., Reichel, M., and Millar, A.A. (2014). Determinants beyond both complementarity and cleavage govern microR159 efficacy in Arabidopsis. Plos Genetics 10, e1004232.

Li, J., Yang, Z., Yu, B., Liu, J., and Chen, X. (2005b). Methylation protects miRNAs and siRNAs from a 3'-end uridylation activity in Arabidopsis. Current Biology 15, 1501-1507.

Li, S.B., Liu, L., Zhuang, X.H., Yu, Y., Liu, X.G., Cui, X., Ji, L.J., Pan, Z.Q., Cao, X.F., Mo, B.X., et al. (2013). MicroRNAs Inhibit the Translation of Target mRNAs on the Endoplasmic Reticulum in Arabidopsis. Cell 153, 562-574.

Liang, D., White, R.G., and Waterhouse, P.M. (2012). Gene silencing in Arabidopsis spreads from the root to the shoot, through a gating barrier, by template-dependent, nonvascular, cell-to-cell movement. Plant Physiology 159, 984-1000.

Lin, D., Xiang, Y., Xian, Z., and Li, Z. (2016). Ectopic expression of SlAGO7 alters leaf pattern and inflorescence architecture and increases fruit yield in tomato. Physiologia plantarum.

Lindroth, A.M., Cao, X., Jackson, J.P., Zilberman, D., McCallum, C.M., Henikoff, S., and Jacobsen, S.E. (2001). Requirement of CHROMOMETHYLASE3 for maintenance of CpXpG methylation. Science 292, 2077-2080. 
Liu, B., Chen, Z.Y., Song, X.W., Liu, C.Y., Cui, X., Zhao, X.F., Fang, J., Xu, W.Y., Zhang, H.Y., Wang, X.J., et al. (2007). Oryza sativa dicer-like4 reveals a key role for small interfering RNA silencing in plant development. Plant Cell 19, 2705-2718.

Liu, Q., Wang, F., and Axtell, M.J. (2014). Analysis of complementarity requirements for plant microRNA targeting using a Nicotiana benthamiana quantitative transient assay. Plant Cell 26, 741-753.

Liu, Q.L., Yao, X.Z., Pi, L.M., Wang, H., Cui, X.F., and Huang, H. (2009a). The ARGONAUTE10 gene modulates shoot apical meristem maintenance and establishment of leaf polarity by repressing miR165/166 in Arabidopsis. Plant Journal 58, 27-40.

Liu, Q.P., Feng, Y., and Zhu, Z.J. (2009b). Dicer-like (DCL) proteins in plants. Functional \& Integrative Genomics 9, 277-286.

Llave, C., Xie, Z., Kasschau, K.D., and Carrington, J.C. (2002). Cleavage of Scarecrow-like mRNA targets directed by a class of Arabidopsis miRNA. Science 297, 2053-2056.

Lobbes, D., Rallapalli, G., Schmidt, D.D., Martin, C., and Clarke, J. (2006). SERRATE: a new player on the plant microRNA scene. EMBO Rep 7, 1052-1058.

Lu, C., Tej, S.S., Luo, S., Haudenschild, C.D., Meyers, B.C., and Green, P.J. (2005). Elucidation of the small RNA component of the transcriptome. Science 309, 1567-1569.

Ma, X.F., Nicole, M.C., Meteignier, L.V., Hong, N., Wang, G.P., and Moffett, P. (2015). Different roles for RNA silencing and RNA processing components in virus recovery and virus-induced gene silencing in plants. Journal of Experimental Botany 66, 919-932.

Malagnac, F., Bartee, L., and Bender, J. (2002). An Arabidopsis SET domain protein required for maintenance but not establishment of DNA methylation. The EMBO journal 21, 6842-6852.

Mallory, A.C., and Bouche, N. (2008). MicroRNA-directed regulation: to cleave or not to cleave. Trends in Plant Science 13, 359-367.

Mallory, A.C., Elmayan, T., and Vaucheret, H. (2008). MicroRNA maturation and action - the expanding roles of ARGONAUTEs. Current Opinion in Plant Biology 11, 560-566.

Mallory, A.C., Reinhart, B.J., Jones-Rhoades, M.W., Tang, G., Zamore, P.D., Barton, M.K., and Bartel, D.P. (2004). MicroRNA control of PHABULOSA in leaf development: importance of pairing to the microRNA 5' region. The EMBO journal 23, 3356-3364.

Manavella, P.A., Hagmann, J., Ott, F., Laubinger, S., Franz, M., Macek, B., and Weigel, D. (2012). Fast-Forward Genetics Identifies Plant CPL Phosphatases as Regulators of miRNA Processing Factor HYL1. Cell 151, 859-870.

Margis, R., Fusaro, A.F., Smith, N.A., Curtin, S.J., Watson, J.M., Finnegan, E.J., and Waterhouse, P.M. (2006). The evolution and diversification of Dicers in plants. FEBS Letters 580, 2442-2450.

Margulis, L., and Schwartz, K.V. (1998). Five kingdoms : an illustrated guide to the phyla of life on earth, 3rd edn (New York: W.H. Freeman).

Marin-Gonzalez, E., and Suarez-Lopez, P. (2012). "And yet it moves": Cell-to-cell and long-distance signaling by plant microRNAs. Plant Science 196, 18-30.

Marrocco, K., Criqui, M.C., Zervudacki, J., Schott, G., Eisler, H., Parnet, A., Dunoyer, P., and Genschik, P. (2012). APC/C-Mediated Degradation of dsRNA-Binding Protein 4 (DRB4) Involved in RNA Silencing. Plos One 7, e35173-e35173.

Matzke, M.A., and Birchler, J.A. (2005). RNAi-mediated pathways in the nucleus. Nature Reviews Genetics 6, 24-35. 
Matzke, M.A., Kanno, T., and Matzke, A.J. (2015). RNA-Directed DNA Methylation: The Evolution of a Complex Epigenetic Pathway in Flowering Plants. Annual review of plant biology 66, 243-267.

McCue, A.D., Panda, K., Nuthikattu, S., Choudury, S.G., Thomas, E.N., and Slotkin, R.K. (2015). ARGONAUTE 6 bridges transposable element mRNA-derived siRNAs to the establishment of DNA methylation. The EMBO journal 34, 20-35.

McHale, N.A., and Koning, R.E. (2004). MicroRNA-directed cleavage of Nicoltiana sylvestris PHAVOLUTA mRNA regulates the vascular cambium and structure of apical Meristems. Plant Cell 16, 1730-1740.

Meng, Y., and Shao, C. (2012). Large-scale identification of mirtrons in Arabidopsis and rice. Plos One 7, e31163.

Mette, M.F., Aufsatz, W., van der Winden, J., Matzke, M.A., and Matzke, A.J. (2000). Transcriptional silencing and promoter methylation triggered by double-stranded RNA. The EMBO journal 19, 5194-5201.

Mi, S., Cai, T., Hu, Y., Chen, Y., Hodges, E., Ni, F., Wu, L., Li, S., Zhou, H., Long, C., et al. (2008). Sorting of small RNAs into Arabidopsis argonaute complexes is directed by the 5' terminal nucleotide. Cell 133, 116-127.

Migicovsky, Z., and Kovalchuk, I. (2014). Transgenerational changes in plant physiology and in transposon expression in response to UV-C stress in Arabidopsis thaliana. Plant Signaling and Behavior 9, e976490-e976490.

Migicovsky, Z., and Kovalchuk, I. (2015). Transgenerational inheritance of epigenetic response to cold in Arabidopsis thaliana. Biocatalysis and Agricultural Biotechnology 4, 1-10.

Migicovsky, Z., Yao, Y., and Kovalchuk, I. (2014). Transgenerational phenotypic and epigenetic changes in response to heat stress in Arabidopsis thaliana. Plant Signaling and Behavior 9.

Minoia, S., Carbonell, A., Di Serio, F., Gisel, A., Carrington, J.C., Navarro, B., and Flores, R. (2014). Specific Argonautes Selectively Bind Small RNAs Derived from Potato Spindle Tuber Viroid and Attenuate Viroid Accumulation In Vivo. Journal of Virology 88, 11933-11945.

Mirzaei, K., Bahramnejad, B., Shamsifard, M.H., and Zamani, W. (2014). In Silico Identification, Phylogenetic and Bioinformatic Analysis of Argonaute Genes in Plants. International Journal of Genomics 2014, 967461-967461.

Mlotshwa, S., Pruss, G.J., Peragine, A., Endres, M.W., Li, J.J., Chen, X.M., Poethig, R.S., Bowman, L.H., and Vance, V. (2008). DICER-LIKE2 Plays a Primary Role in Transitive Silencing of Transgenes in Arabidopsis. Plos One 3, e1755-e1755.

Moissiard, G., Parizotto, E.A., Himber, C., and Voinnet, O. (2007). Transitivity in Arabidopsis can be primed, requires the redundant action of the antiviral Dicer-like 4 and Dicer-like 2, and is compromised by viral-encoded suppressor proteins. RNA 13, 1268-1278.

Moissiard, G., and Voinnet, O. (2006). RNA silencing of host transcripts by cauliflower mosaic virus requires coordinated action of the four Arabidopsis Dicer-like proteins (Retracted article. See vol. 112, pg. E4818, 2015). Proc Natl Acad Sci U S A 103, 19593-19598.

Montgomery, T.A., Howell, M.D., Cuperus, J.T., Li, D.W., Hansen, J.E., Alexander, A.L., Chapman, E.J., Fahlgren, N., Allen, E., and Carrington, J.C. (2008). Specificity of ARGONAUTE7-miR390 interaction and dual functionality in TAS3 trans-acting siRNA formation. Cell 133, 128-141.

Morel, J.B., Godon, C., Mourrain, P., Beclin, C., Boutet, S., Feuerbach, F., Proux, F., and Vaucheret, H. (2002). Fertile hypomorphic ARGONAUTE (ago1) mutants impaired in post-transcriptional gene silencing and virus resistance. Plant Cell 14, 629-639. 
Mourrain, P., Beclin, C., Elmayan, T., Feuerbach, F., Godon, C., Morel, J.B., Jouette, D., Lacombe, A.M., Nikic, S., Picault, N., et al. (2000). Arabidopsis SGS2 and SGS3 genes are required for posttranscriptional gene silencing and natural virus resistance. Cell 101, 533-542.

Muangsan, N., Beclin, C., Vaucheret, H., and Robertson, D. (2004). Geminivirus VIGS of endogenous genes requires SGS2/SDE1 and SGS3 and defines a new branch in the genetic pathway for silencing in plants. Plant Journal 38, 1004-1014.

Mukherjee, K., Campos, H., and Kolaczkowski, B. (2013). Evolution of Animal and Plant Dicers: Early Parallel Duplications and Recurrent Adaptation of Antiviral RNA Binding in Plants. Molecular Biology and Evolution 30, 627-641.

Nagano, H., Fukudome, A., Hiraguri, A., Moriyama, H., and Fukuhara, T. (2014). Distinct substrate specificities of Arabidopsis DCL3 and DCL4. Nucleic Acids Research 42, 1845-1856.

Nagasaki, H., Itoh, J.-I., Hayashi, K., Hibara, K.-I., Satoh-Nagasawa, N., Nosaka, M., Mukouhata, M., Ashikari, M., Kitano, H., Matsuoka, M., et al. (2007). The small interfering RNA production pathway is required for shoot meristern initiation in rice. Proc Natl Acad Sci U S A 104, 14867-14871.

Nakazawa, Y., Hiraguri, A., Moriyama, H., and Fukuhara, T. (2007). The dsRNA-binding protein DRB4 interacts with the Dicer-like protein DCL4 in vivo and functions in the trans-acting siRNA pathway. Plant Molecular Biology 63, 777-785.

Odokonyero, D., Mendoza, M.R., Alvarado, V.Y., Zhang, J.T., Wang, X.F., and Scholthof, H.B. (2015). Transgenic down-regulation of ARGONAUTE2 expression in Nicotiana benthamiana interferes with several layers of antiviral defenses. Virology 486, 209-218.

Ogwok, E., Ilyas, M., Alicai, T., Rey, M.E.C., and Taylor, N.J. (2016). Comparative analysis of virus-derived small RNAs within cassava (Manihot esculenta Crantz) infected with cassava brown streak viruses. Virus Research 215, 1-11.

Oliver, C., Santos, J.L., and Pradillo, M. (2014). On the role of some ARGONAUTE proteins in meiosis and DNA repair in Arabidopsis thaliana. Frontiers in Plant Science 5, 177-177.

Olmedo-Monfil, V., Duran-Figueroa, N., Arteaga-Vazquez, M., Demesa-Arevalo, E., Autran, D., Grimanelli, D., Slotkin, R.K., Martienssen, R.A., and Vielle-Calzada, J.P. (2010). Control of female gamete formation by a small RNA pathway in Arabidopsis. Nature 464, 628-U200.

Onodera, Y., Haag, J.R., Ream, T., Nunes, P.C., Pontes, O., and Pikaard, C.S. (2005). Plant nuclear RNA polymerase IV mediates siRNA and DNA methylation-dependent heterochromatin formation. Cell 120, 613-622.

Palmer, J.D., Soltis, D.E., and Chase, M.W. (2004). The plant tree of life: an overview and some points of view. American journal of botany 91, 1437-1445.

Papp, I., Mette, M.F., Aufsatz, W., Daxinger, L., Schauer, S.E., Ray, A., van der Winden, J., Matzke, M., and Matzke, A.J.M. (2003). Evidence for nuclear processing of plant micro RNA and short interfering RNA precursors. Plant Physiology 132, 1382-1390.

Parent, J.S., Bouteiller, N., Elmayan, T., and Vaucheret, H. (2015). Respective contributions of Arabidopsis DCL2 and DCL4 to RNA silencing. Plant Journal 81, 223-232.

Park, M.Y., Wu, G., Gonzalez-Sulser, A., Vaucheret, H., and Poethig, R.S. (2005). Nuclear processing and export of microRNAs in Arabidopsis. Proc Natl Acad Sci U S A 102, 3691-3696.

Park, W., Li, J.J., Song, R.T., Messing, J., and Chen, X.M. (2002). CARPEL FACTORY, a Dicer homolog, and HEN1, a novel protein, act in microRNA metabolism in Arabidopsis thaliana. Current Biology 12, 1484-1495. 
Pelissier, T., Clavel, M., Chaparro, C., Pouch-Pelissier, M.N., Vaucheret, H., and Deragon, J.M. (2011). Double-stranded RNA binding proteins DRB2 and DRB4 have an antagonistic impact on polymerase IV-dependent siRNA levels in Arabidopsis. RNA 17, 1502-1510.

Pelissier, T., Thalmeir, S., Kempe, D., Sanger, H.L., and Wassenegger, M. (1999). Heavy de novo methylation at symmetrical and non-symmetrical sites is a hallmark of RNA-directed DNA methylation. Nucleic Acids Research 27, 1625-1634.

Pelissier, T., and Wassenegger, M. (2000). A DNA target of $30 \mathrm{bp}$ is sufficient for RNA-directed DNA methylation. RNA 6, 55-65.

Penterman, J., Zilberman, D., Huh, J.H., Ballinger, T., Henikoff, S., and Fischer, R.L. (2007). DNA demethylation in the Arabidopsis genome. Proc Natl Acad Sci U S A 104, 6752-6757.

Peragine, A., Yoshikawa, M., Wu, G., Albrecht, H.L., and Poethig, R.S. (2004). SGS3 and SGS2/ SDE1/RDR6 are required for juvenile development and the production of trans-acting siRNAs in Arabidopsis. Genes \& Development 18, 2368-2379.

Pontes, O., Li, C.F., Nunes, P.C., Haag, J., Ream, T., Vitins, A., Jacobsen, S.E., and Pikaard, C.S. (2006). The Arabidopsis chromatin-modifying nuclear siRNA pathway involves a nucleolar RNA processing center. Cell 126, 79-92.

Pontier, D., Picart, C., Roudier, F., Garcia, D., Lahmy, S., Azevedo, J., Alart, E., Laudie, M., Karlowski, W.M., Cooke, R., et al. (2012). NERD, a Plant-Specific GW Protein, Defines an Additional RNAi-Dependent Chromatin-Based Pathway in Arabidopsis. Molecular Cell 48, 121-132.

Pouch-Pelissier, M.-N., Pelissier, T., Elmayan, T., Vaucheret, H., Boko, D., Jantsch, M.F., and Deragon, J.-M. (2008). SINE RNA Induces Severe Developmental Defects in Arabidopsis thaliana and Interacts with HYL1 (DRB1), a Key Member of the DCL1 Complex. Plos Genetics 4, e1000096-e1000096.

Qu, F., Ye, X.H., Hou, G.C., Sato, S., Clemente, T.E., and Morris, T.J. (2005). RDR6 has a broad-spectrum but temperature-dependent antiviral defense role in Nicotiana benthamiana. Journal of Virology 79, 15209-15217.

Qu, F., Ye, X.H., and Morris, T.J. (2008). Arabidopsis DRB4, AG01, AG07, and RDR6 participate in a DCL4-initiated antiviral RNA silencing pathway negatively regulated by DCL1. Proc Natl Acad Sci U S A 105, 14732-14737.

Raghuram, B., Sheikh, A.H., Rustagi, Y., and Sinha, A.K. (2015). MicroRNA biogenesis factor DRB1 is a phosphorylation target of mitogen activated protein kinase MPK3 in both rice and Arabidopsis. FEBS Journal 282, 521-536.

Raja, P., Jackel, J.N., Li, S.Z., Heard, I.M., and Bisaro, D.M. (2014). Arabidopsis Double-Stranded RNA Binding Protein DRB3 Participates in Methylation-Mediated Defense against Geminiviruses. Journal of Virology 88, 2611-2622.

Rajagopalan, R., Vaucheret, H., Trejo, J., and Bartel, D.P. (2006). A diverse and evolutionarily fluid set of microRNAs in Arabidopsis thaliana. Genes \& Development 20, 3407-3425.

Reinhart, B.J., Weinstein, E.G., Rhoades, M.W., Bartel, B., and Bartel, D.P. (2002). MicroRNAs in plants. Genes \& Development 16, 1616-1626.

Reis, R.S., Eamens, A.L., Roberts, T.H., and Waterhouse, P.M. (2016). Chimeric DCL1-Partnering Proteins Provide Insights into the MicroRNA Pathway. Frontiers in Plant Science 6.

Reis, R.S., Eamens, A.L., and Waterhouse, P.M. (2015a). Missing Pieces in the Puzzle of Plant MicroRNAs. Trends in Plant Science 20, 721-728. 
Reis, R.S., Hart-Smith, G., Eamens, A.L., Wilkins, M.R., and Waterhouse, P.M. (2015b). Gene regulation by translational inhibition is determined by Dicer partnering proteins. Nature Plants 1 .

Reis, R.S., Hart-Smith, G., Eamens, A.L., Wilkins, M.R., and Waterhouse, P.M. (2015c). MicroRNA Regulatory Mechanisms Play Different Roles in Arabidopsis. Journal of Proteome Research 14, 4743-4751.

Ren, G.D., Xie, M., Zhang, S.X., Vinovskis, C., Chen, X.M., and Yu, B. (2014). Methylation protects microRNAs from an AGO1-associated activity that uridylates 5' RNA fragments generated by AGO1 cleavage. Proc Natl Acad Sci U S A 111, 6365-6370.

Rhoades, M.W., Reinhart, B.J., Lim, L.P., Burge, C.B., Bartel, B., and Bartel, D.P. (2002). Prediction of plant microRNA targets. Cell 110, 513-520.

Rodriguez, R.E., Mecchia, M.A., Debernardi, J.M., Schommer, C., Weigel, D., and Palatnik, J.F. (2010). Control of cell proliferation in Arabidopsis thaliana by microRNA miR396. Development 137, 103-112.

Rogers, K., and Chen, X.M. (2013). Biogenesis, Turnover, and Mode of Action of Plant MicroRNAs. Plant Cell 25, 2383-2399.

Roodbarkelari, F., Du, F., Truernit, E., and Laux, T. (2015). ZLL/AGO10 maintains shoot meristem stem cells during Arabidopsis embryogenesis by down-regulating ARF2-mediated auxin response. BMC Biology 13, 74-74.

Salgado, P.S., Koivunen, M.R.L., Makeyev, E.V., Bamford, D.H., Stuart, D.I., and Grimes, J.M. (2006). The structure of an RNAi polymerase links RNA silencing and transcription. Plos Biology 4, 2274-2281.

Schauer, S.E., Jacobsen, S.E., Meinke, D.W., and Ray, A. (2002). DICER-LIKE1: blind men and elephants in Arabidopsis development. Trends in Plant Science 7, 487-491.

Schiebel, W., Haas, B., Marinkovic, S., Klanner, A., and Sanger, H.L. (1993). RNA-directed RNA polymerase from tomato leaves. II. Catalytic in vitro properties. Journal of Biological Chemistry 268, 11858-11867.

Schiebel, W., Pelissier, T., Riedel, L., Thalmeir, S., Schiebel, R., Kempe, D., Lottspeich, F., Sanger, H.L., and Wassenegger, M. (1998). Isolation of an RNA-Directed RNA polymerase-specific cDNA clone from tomato. Plant Cell 10, 2087-2101.

Schwab, R., Palatnik, J.F., Riester, M., Schommer, C., Schmid, M., and Weigel, D. (2005). Specific effects of microRNAs on the plant transcriptome. Developmental Cell 8, 517-527.

Shao, C.G., Chen, M., and Meng, Y.J. (2013). A reversed framework for the identification of microRNA-target pairs in plants. Briefings in Bioinformatics 14, 293-301.

Shao, F.J., and Lu, S.F. (2013). Genome-wide identification, molecular cloning, expression profiling and posttranscriptional regulation analysis of the Argonaute gene family in Salvia miltiorrhiza, an emerging model medicinal plant. BMC Genomics 14, 512-512.

Shao, F.J., and Lu, S.F. (2014). Identification, Molecular Cloning and Expression Analysis of Five RNA-Dependent RNA Polymerase Genes in Salvia miltiorrhiza. Plos One 9, e95117-e95117.

Shi, Z.Y., Wang, J., Wan, X.S., Shen, G.Z., Wang, X.Q., and Zhang, J.L. (2007). Over-expression of rice OsAGO7 gene induces upward curling of the leaf blade that enhanced erect-leaf habit. Planta 226, 99-108.

Shivaprasad, P.V., Rajeswaran, R., Blevins, T., Schoelz, J., Meins, F., Hohn, T., and Pooggin, M.M. (2008). The CaMV transactivator/viroplasmin interferes with RDR6-dependent trans-acting and secondary siRNA pathways in Arabidopsis. Nucleic Acids Research 36, 5896-5909. 
Silva, T.F., Romanel, E.A.C., Andrade, R.R.S., Farinelli, L., Osteras, M., Deluen, C., Correa, R.L., Schrago, C.E.G., and Vaslin, M.F.S. (2011). Profile of small interfering RNAs from cotton plants infected with the polerovirus Cotton leafroll dwarf virus. BMC Molecular Biology 12, 40-40.

Singh, M., Goel, S., Meeley, R.B., Dantec, C., Parrinello, H., Michaud, C., Leblanc, O., and Grimanelli, D. (2011). Production of Viable Gametes without Meiosis in Maize Deficient for an ARGONAUTE Protein. Plant Cell 23, 443-458.

Smith, M.R., Willmann, M.R., Wu, G., Berardini, T.Z., Moller, B., Weijers, D., and Poethig, R.S. (2009). Cyclophilin 40 is required for microRNA activity in Arabidopsis. Proc Natl Acad Sci U S A 106, 5424-5429.

Song, X.W., Li, P.C., Zhai, J.X., Zhou, M., Ma, L.J., Liu, B., Jeong, D.H., Nakano, M., Cao, S.Y., Liu, C.Y., et al. (2012). Roles of DCL4 and DCL3b in rice phased small RNA biogenesis. Plant Journal 69, 462-474.

Souret, F.F., Kastenmayer, J.P., and Green, P.J. (2004). AtXRN4 degrades mRNA in Arabidopsis and its substrates include selected miRNA targets. Molecular Cell 15, 173-183.

Sunkar, R., and Zhu, J.K. (2004). Novel and stress-regulated microRNAs and other small RNAs from Arabidopsis. Plant Cell 16, 2001-2019.

Svoboda, P., and Cara, A.D. (2006). Hairpin RNA: a secondary structure of primary importance. Cell Mol Life Sci 63, 901-908.

Takeda, A., Iwasaki, S., Watanabe, T., Utsumi, M., and Watanabe, Y. (2008). The mechanism selecting the guide strand from small RNA duplexes is different among Argonaute proteins. Plant and Cell Physiology 49, 493-500.

Thomas, C.L., Jones, L., Baulcombe, D.C., and Maule, A.J. (2001). Size constraints for targeting post-transcriptional gene silencing and for RNA-directed methylation in Nicotiana benthamiana using a potato virus X vector. Plant Journal 25, 417-425.

Tkaczuk, K.L., Obarska, A., and Bujnicki, J.M. (2006). Molecular phylogenetics and comparative modeling of HEN1, a methyltransferase involved in plant microRNA biogenesis. BMC Evolutionary Biology 6, 6-6.

Tucker, M.R., Okada, T., Hu, Y., Scholefield, A., Taylor, J.M., and Koltunow, A.M. (2012). Somatic small RNA pathways promote the mitotic events of megagametogenesis during female reproductive development in Arabidopsis. Development 139, 1399-1404.

Tucker, M.R., Roodbarkelari, F., Truernit, E., Adamski, N.M., Hinze, A., Lohmuller, B., Wurschum, T., and Laux, T. (2013). Accession-specific modifiers act with ZWILLE/ARGONAUTE10 to maintain shoot meristem stem cells during embryogenesis in Arabidopsis. BMC Genomics 14, 809-809.

Tworak, A., Urbanowicz, A., Podkowinski, J., Kurzynska-Kokorniak, A., Koralewska, N., and Figlerowicz, M. (2016). Six Medicago truncatula Dicer-like protein genes are expressed in plant cells and upregulated in nodules. Plant Cell Reports 35, 1043-1052.

Urayama, S., Moriyama, H., Aoki, N., Nakazawa, Y., Okada, R., Kiyota, E., Miki, D., Shimamoto, K., and Fukuhara, T. (2010). Knock-down of OsDCL2 in Rice Negatively Affects Maintenance of the Endogenous dsRNA Virus, Oryza sativa Endornavirus. Plant and Cell Physiology 51, $58-67$.

Vaistij, F.E., Jones, L., and Baulcombe, D.C. (2002). Spreading of RNA targeting and DNA methylation in RNA silencing requires transcription of the target gene and a putative RNA-dependent RNA polymerase. Plant Cell 14, 857-867. 
Van Ex, F., Jacob, Y., and Martienssen, R.A. (2011). Multiple roles for small RNAs during plant reproduction. Current Opinion in Plant Biology 14, 588-593.

Vaucheret, H. (2005). MicroRNA-dependent trans-acting siRNA production. Science's STKE : signal transduction knowledge environment 2005, pe43-pe43.

Vaucheret, H. (2008). Plant ARGONAUTES. Trends in Plant Science 13, 350-358.

Vaucheret, H., Vazquez, F., Crete, P., and Bartel, D.P. (2004). The action of ARGONAUTE1 in the miRNA pathway and its regulation by the miRNA pathway are crucial for plant development. Genes \& Development 18, 1187-1197.

Vazquez, F. (2006). Arabidopsis endogenous small RNAs: highways and byways. Trends in Plant Science 11, 460-468.

Vazquez, F., Gasciolli, V., Crete, P., and Vaucheret, H. (2004). The nuclear dsRNA binding protein HYL1 is required for MicroRNA accumulation and plant development, but not posttranscriptional transgene silencing. Current Biology 14, 346-351.

Vongs, A., Kakutani, T., Martienssen, R.A., and Richards, E.J. (1993). Arabidopsis thaliana DNA methylation mutants. Science 260, 1926-1928.

Wang, X.B., Jovel, J., Udomporn, P., Wang, Y., Wu, Q.F., Li, W.X., Gasciolli, V., Vaucheret, H., and Ding, S.W. (2011). The 21-Nucleotide, but Not 22-Nucleotide, Viral Secondary Small Interfering RNAs Direct Potent Antiviral Defense by Two Cooperative Argonautes in Arabidopsis thaliana. Plant Cell 23, 1625-1638.

Wang, X.B., Wu, Q.F., Ito, T., Cillo, F., Li, W.X., Chen, X.M., Yu, J.L., and Ding, S.W. (2010). RNAi-mediated viral immunity requires amplification of virus-derived siRNAs in Arabidopsis thaliana. Proc Natl Acad Sci U S A 107, 484-489.

Wassenegger, M., Heimes, S., Riedel, L., and Sanger, H.L. (1994). RNA-directed de novo methylation of genomic sequences in plants. Cell 76, 567-576.

Wassenegger, M., and Krczal, G. (2006). Nomenclature and functions of RNA-directed RNA polymerases. Trends in Plant Science 11, 142-151.

Wei, L.Y., Gu, L.F., Song, X.W., Cui, X.K., Lu, Z.K., Zhou, M., Wang, L.L., Hu, F.Y., Zhai, J.X., Meyers, B.C., et al. (2014). Dicer-like 3 produces transposable element-associated 24-nt siRNAs that control agricultural traits in rice. Proc Natl Acad Sci U S A 111, 3877-3882.

Wei, W., Ba, Z., Gao, M., Wu, Y., Ma, Y., Amiard, S., White, C.I., Rendtlew Danielsen, J.M., Yang, Y.G., and Qi, Y. (2012). A role for small RNAs in DNA double-strand break repair. Cell 149, $101-112$.

Wu, J.G., Yang, Z.R., Wang, Y., Zheng, L.J., Ye, R.Q., Ji, Y.H., Zhao, S.S., Ji, S.Y., Liu, R.F., Xu, L., et al. (2015). Viral-Inducible Argonaute 18 Confers Broad-Spectrum Virus Resistance in Rice by Sequestering A Host MicroRNA. Elife 4.

Wu, L., Mao, L., and Qi, Y.J. (2012). Roles of DICER-LIKE and ARGONAUTE Proteins in TAS-Derived Small Interfering RNA-Triggered DNA Methylation. Plant Physiology 160, 990-999.

Wu, L., Zhang, Q.Q., Zhou, H.Y., Ni, F.R., Wu, X.Y., and Qi, Y.J. (2009). Rice MicroRNA Effector Complexes and Targets. Plant Cell 21, 3421-3435.

Wu, L., Zhou, H.Y., Zhang, Q.Q., Zhang, J.G., Ni, F.R., Liu, C., and Qi, Y.J. (2010). DNA Methylation Mediated by a MicroRNA Pathway. Molecular Cell 38, 465-475.

Xie, M., and Yu, B. (2015). siRNA-directed DNA Methylation in Plants. Current Genomics 16, 23-31. 
Xie, Z.X., Allen, E., Wilken, A., and Carrington, J.C. (2005). DICER-LIKE 4 functions in trans-acting small interfering RNA biogenesis and vegetative phase change in Arabidopsis thaliana. Proc Natl Acad Sci U S A 102, 12984-12989.

Xie, Z.X., Johansen, L.K., Gustafson, A.M., Kasschau, K.D., Lellis, A.D., Zilberman, D., Jacobsen, S.E., and Carrington, J.C. (2004). Genetic and functional diversification of small RNA pathways in plants. Plos Biology 2, 642-652.

Xie, Z.X., Kasschau, K.D., and Carrington, J.C. (2003). Negative feedback regulation of Dicer-Like1 in Arabidopsis by microRNA-guided mRNA degradation. Current Biology 13, 784-789.

Xie, Z.X., Khanna, K., and Ruan, S.L. (2010). Expression of microRNAs and its regulation in plants. Seminars in Cell \& Developmental Biology 21, 790-797.

Yang, L., Liu, Z.Q., Lu, F., Dong, A.W., and Huang, H. (2006). SERRATE is a novel nuclear regulator in primary microRNA processing in Arabidopsis. Plant Journal 47, 841-850.

Yang, L., Wu, G., and Poethig, R.S. (2012). Mutations in the GW-repeat protein SUO reveal a developmental function for microRNA-mediated translational repression in Arabidopsis. Proc Natl Acad Sci U S A 109, 315-320.

Yang, S.J., Carter, S.A., Cole, A.B., Cheng, N.H., and Nelson, R.S. (2004). A natural variant of a host RNA-dependent RNA polymerase is associated with increased susceptibility to viruses by Nicotiana benthamiana. Proc Natl Acad Sci U S A 101, 6297-6302.

You, C.X., Zhao, Q., Wang, X.F., Xie, X.B., Feng, X.M., Zhao, L.L., Shu, H.R., and Hao, Y.J. (2014). A dsRNA-binding protein MdDRB1 associated with miRNA biogenesis modifies adventitious rooting and tree architecture in apple. Plant Biotechnology Journal 12, 183-192.

Yu, B., Yang, Z., Li, J., Minakhina, S., Yang, M., Padgett, R.W., Steward, R., and Chen, X. (2005). Methylation as a crucial step in plant microRNA biogenesis. Science 307, 932-935.

Yu, D.Q., Fan, B.F., MacFarlane, S.A., and Chen, Z.X. (2003). Analysis of the involvement of an inducible Arabidopsis RNA-dependent RNA polymerase in antiviral defense. Molecular Plant-Microbe Interactions 16, 206-216.

Zhai, L., Sun, W., Zhang, K., Jia, H., Liu, L., Liu, Z., Teng, F., and Zhang, Z. (2014). Identification and characterization of Argonaute gene family and meiosis-enriched Argonaute during sporogenesis in maize. J Integr Plant Biol 56, 1042-1052.

Zhang, H., Xia, R., Meyers, B.C., and Walbot, V. (2015). Evolution, functions, and mysteries of plant ARGONAUTE proteins. Current Opinion in Plant Biology 27, 84-90.

Zhang, W.X., Gao, S., Zhou, X.F., Xia, J., Chellappan, P., Zhou, X.A., Zhang, X.M., and Jin, H.L. (2010). Multiple distinct small RNAs originate from the same microRNA precursors. Genome Biology 11, R81-R81.

Zhang, X., Henderson, I.R., Lu, C., Green, P.J., and Jacobsen, S.E. (2007). Role of RNA polymerase IV in plant small RNA metabolism. Proc Natl Acad Sci U S A 104, 4536-4541.

Zhang, X., Zhao, H., Gao, S., Wang, W.C., Katiyar-Agarwal, S., Huang, H.D., Raikhel, N., and Jin, H. (2011). Arabidopsis Argonaute 2 regulates innate immunity via miRNA393(*)-mediated silencing of a Golgi-localized SNARE gene, MEMB12. Molecular Cell 42, 356-366.

Zhang, X.C., Zhang, X.F., Singh, J., Li, D.W., and Qu, F. (2012). Temperature-Dependent Survival of Turnip Crinkle Virus-Infected Arabidopsis Plants Relies on an RNA Silencing-Based Defense That Requires DCL2, AG02, and HEN1. Journal of Virology 86, 6847-6854.

Zhao, X., Zhang, H., and Li, L. (2013). Identification and analysis of the proximal promoters of microRNA genes in Arabidopsis. Genomics 101, 187-194. 
Zheng, B., Wang, Z., Li, S., Yu, B., Liu, J.-Y., and Chen, X. (2009). Intergenic transcription by RNA Polymerase II coordinates Pol IV and Pol V in siRNA-directed transcriptional gene silencing in Arabidopsis. Genes \& Development 23, 2850-2860.

Zheng, X.W., Zhu, J.H., Kapoor, A., and Zhu, J.K. (2007). Role of Arabidopsis AGO6 in siRNA accumulation, DNA methylation and transcriptional gene silencing. The EMBO journal 26, 1691-1701.

Zhou, C., Han, L., Fu, C., Wen, J., Cheng, X., Nakashima, J., Ma, J., Tang, Y., Tan, Y., Tadege, M., et al. (2013). The Trans-Acting Short Interfering RNA3 Pathway and NO APICAL MERISTEM Antagonistically Regulate Leaf Margin Development and Lateral Organ Separation, as Revealed by Analysis of an argonaute7/lobed leaflet1 Mutant in Medicago truncatula. Plant Cell $25,4845-4862$.

Zhou, Y., Honda, M., Zhu, H., Zhang, Z., Guo, X., Li, T., Li, Z., Peng, X., Nakajima, K., Duan, L., et al. (2015). Spatiotemporal Sequestration of miR165/166 by Arabidopsis Argonaute10 Promotes Shoot Apical Meristem Maintenance. Cell Reports 10, 1819-1827.

Zhu, H., Zhou, Y., Castillo-Gonzalez, C., Lu, A., Ge, C., Zhao, Y.T., Duan, L., Li, Z., Axtell, M.J., Wang, X.J., et al. (2013). Bidirectional processing of pri-miRNAs with branched terminal loops by Arabidopsis Dicer-like1. Nature Structural \& Molecular Biology 20, 1106-1115.

Zhu, H.L., Hu, F.Q., Wang, R.H., Zhou, X., Sze, S.H., Liou, L.W., Barefoot, A., Dickman, M., and Zhang, X.R. (2011). Arabidopsis Argonaute10 Specifically Sequesters miR166/165 to Regulate Shoot Apical Meristem Development. Cell 145, 242-256.

Zilberman, D., Cao, X.F., Johansen, L.K., Xie, Z.X., Carrington, J.C., and Jacobsen, S.E. (2004). Role of arabidopsis ARGONAUTE4 in RNA-directed DNA methylation triggered by inverted repeats. Current Biology 14, 1214-1220. 